\title{
Planetary Boundaries: Exploring the Safe Operating Space for Humanity
}

\author{
$\underline{\text { Johan Rockström }}^{1,2}$, Will Steffen $^{1,3}, \underline{\text { Kevin Noone }}^{1,4},{ }_{\text {Asa Persson }}^{1,2}$, F. Stuart III Chapin $^{5}$, Eric Lambin ${ }^{6}$, \\ Timothy M. Lenton $^{7}$, Marten Scheffer ${ }^{8}$, Carl Folke ${ }^{1,9}$, Hans Joachim Schellnhuber ${ }^{10,11}$, Björn Nykvist ${ }^{1,2}$, \\ Cynthia A. de Wit $^{4}$, Terry Hughes ${ }^{12}$, Sander van der Leeuw ${ }^{13}$, Henning Rodhe ${ }^{14}$, Sverker Sörlin ${ }^{1,15}$, \\ Peter K. Snyder ${ }^{16}$, Robert Costanza ${ }^{1,17}$, Uno Svedin ${ }^{1}$, Malin Falkenmark ${ }^{1,18}$, Louise Karlberg ${ }^{1,2}$, \\ $\underline{\text { Robert W. Corell }}^{19}$, Victoria J. Fabry $^{20}$, James Hansen $^{21}$ Brian Walker $^{1,22}$, Diana Liverman $^{23,24}$, \\ Katherine Richardson $^{25}$, Paul Crutzen ${ }^{26}$, and Jonathan Foley ${ }^{27}$
}

ABSTRACT. Anthropogenic pressures on the Earth System have reached a scale where abrupt global environmental change can no longer be excluded. We propose a new approach to global sustainability in which we define planetary boundaries within which we expect that humanity can operate safely. Transgressing one or more planetary boundaries may be deleterious or even catastrophic due to the risk of crossing thresholds that will trigger non-linear, abrupt environmental change within continental- to planetary-scale systems. We have identified nine planetary boundaries and, drawing upon current scientific understanding, we propose quantifications for seven of them. These seven are climate change $\left(\mathrm{CO}_{2}\right.$ concentration in the atmosphere $<350 \mathrm{ppm}$ and/or a maximum change of $+1 \mathrm{~W} \mathrm{~m}^{-2}$ in radiative forcing); ocean acidification (mean surface seawater saturation state with respect to aragonite $\geq 80 \%$ of pre-industrial levels); stratospheric ozone ( $<5 \%$ reduction in $\mathrm{O}_{3}$ concentration from pre-industrial level of 290 Dobson Units); biogeochemical nitrogen (N) cycle (limit industrial and agricultural fixation of $\mathrm{N}_{2}$ to $35 \mathrm{Tg} \mathrm{N} \mathrm{yr}^{-1}$ ) and phosphorus (P) cycle (annual P inflow to oceans not to exceed 10 times the natural background weathering of P); global freshwater use $\left(<4000 \mathrm{~km}^{3} \mathrm{yr}^{-1}\right.$ of consumptive use of runoff resources); land system change ( $<15 \%$ of the ice-free land surface under cropland); and the rate at which biological diversity is lost (annual rate of $<10$ extinctions per million species). The two additional planetary boundaries for which we have not yet been able to determine a boundary level are chemical pollution and atmospheric aerosol loading. We estimate that humanity has already transgressed three planetary boundaries: for climate change, rate of biodiversity loss, and changes to the global nitrogen cycle. Planetary boundaries are interdependent, because transgressing one may both shift the position of other boundaries or cause them to be transgressed. The social impacts of transgressing boundaries will be a function of the social-ecological resilience of the affected societies. Our proposed boundaries are rough, first estimates only, surrounded by large uncertainties and knowledge gaps. Filling these gaps will require major advancements in Earth System and resilience science. The proposed concept of "planetary boundaries" lays the groundwork for shifting our approach to governance and management, away from the essentially sectoral analyses of limits to growth aimed at minimizing negative externalities, toward the estimation of the safe space for human development. Planetary boundaries define, as it were, the boundaries of the "planetary playing field" for humanity if we want to be sure of avoiding major human-induced environmental change on a global scale.

Key Words: atmospheric aerosol loading; biogeochemical nitrogen cycle; biological diversity; chemical pollution; climate change; Earth; global freshwater use; land system change; ocean acidification; phosphorus cycle; planetary boundaries; stratospheric ozone; sustainability

\footnotetext{
${ }^{1}$ Stockholm Resilience Centre, Stockholm University, ${ }^{2}$ Stockholm Environment Institute, ${ }^{3}$ Australian National University, Australia, ${ }^{4}$ Department of Applied Environmental Science, Stockholm University, ${ }^{5}$ Institute of Arctic Biology, University of Alaska Fairbanks, ${ }^{6}$ Department of Geography, University of

Louvain, ${ }^{7}$ School of Environmental Sciences, University of East Anglia, ${ }^{8}$ Aquatic Ecology and Water Quality Management Group, Wageningen University, ${ }^{9}$ The Beijer Institute of Ecological Economics, Royal Swedish Academy of Sciences, ${ }^{10}$ Potsdam Institute for Climate Impact Research, ${ }_{1}^{1}$ Environmental Change Institute and Tyndall Centre, Oxford University, ${ }_{12}^{2}$ ARC Centre of Excellence for Coral Reef Studies, James Cook University, ${ }^{13}$ School of Human Evolution and Social Change, Arizona State University, ${ }^{14}$ Department of Meteorology, Stockholm University, ${ }^{15}$ Division of History of Science and

Technology, Royal Institute of Technology, ${ }^{16}$ Department of Soil, Water, and Climate, University of Minnesota, ${ }^{17}$ Gund Institute for Ecological Economics, University of Vermont, ${ }^{18}$ Stockholm International Water Institute, ${ }^{19}$ The H. John Heinz III Center for Science, Economics and the Environment,

${ }^{20}$ Department of Biological Sciences, California State University San Marcos, ${ }^{21}$ NASA Goddard Institute for Space Studies, ${ }^{22}$ CSIRO Sustainable

Ecosystems, ${ }^{23}$ Environmental Change Institute, School of Geography and the Environment, ${ }^{24}$ Institute of the Environment, University of Arizona, ${ }^{25}$ Earth

System Science Centre, University of Copenhagen, ${ }^{26}$ Max Planck Institute for Chemistry, ${ }^{27}$ Institute on the Environment, University of Minnesota
} 


\section{NEW CHALLENGES REQUIRE NEW THINKING ON GLOBAL SUSTAINABILITY}

Human activities increasingly influence the Earth's climate (International Panel on Climate Change (IPPC) 2007a) and ecosystems (Millennium Ecosystem Assessment (MEA) 2005a). The Earth has entered a new epoch, the Anthropocene, where humans constitute the dominant driver of change to the Earth System ${ }^{\mathrm{i}}$ (Crutzen 2002, Steffen et al. 2007). The exponential growth of human activities is raising concern that further pressure on the Earth System could destabilize critical biophysical systems and trigger abrupt or irreversible environmental changes that would be deleterious or even catastrophic for human well-being. This is a profound dilemma because the predominant paradigm of social and economic development remains largely oblivious to the risk of humaninduced environmental disasters at continental to planetary scales (Stern 2007).

Here, we present a novel concept, planetary boundaries, for estimating a safe operating space for humanity with respect to the functioning of the Earth System. We make a first preliminary effort at identifying key Earth System processes and attempt to quantify for each process the boundary level that should not be transgressed if we are to avoid unacceptable global environmental change. Unacceptable change is here defined in relation to the risks humanity faces in the transition of the planet from the Holocene to the Anthropocene. The relatively stable environment of the Holocene, the current interglacial period that began about 10000 years ago, allowed agriculture and complex societies, including the present, to develop and flourish (Fig. 1). That stability induced humans, for the first time, to invest in a major way in their natural environment rather than merely exploit it (van der Leeuw 2008). We have now become so dependent on those investments for our way of life, and how we have organized society, technologies, and economies around them, that we must take the range within which Earth System processes varied in the Holocene as a scientific reference point for a desirable planetary state.

Despite some natural environmental fluctuations over the past 10000 years (e.g., rainfall patterns, vegetation distribution, nitrogen cycling), Earth has remained within the Holocene stability domain. The resilience of the planet has kept it within the range of variation associated with the Holocene state, with key biogeochemical and atmospheric parameters fluctuating within a relatively narrow range (Fig. 1; Dansgaard et al. 1993, Petit et al. 1999, Rioual et al. 2001). At the same time, marked changes in regional system dynamics have occurred over that period. Although the imprint of early human activities can sometimes be seen at the regional scale (e.g., altered fire regimes, megafauna extinctions), there is no clear evidence that humans have affected the functioning of the Earth System at the global scale until very recently (Steffen et al. 2007). However, since the industrial revolution (the advent of the Anthropocene), humans are effectively pushing the planet outside the Holocene range of variability for many key Earth System processes (Steffen et al. 2004). Without such pressures, the Holocene state may be maintained for thousands of years into the future (Berger and Loutre 2002).

So far, science has provided warnings of planetary risks of crossing thresholds in the areas of climate change and stratospheric ozone (IPCC 1990, 2007a, b, World Meteorological Organization 1990). However, the growing human pressure on the planet (Vitousek et al. 1997, MEA 2005a) necessitates attention to other biophysical processes that are of significance to the resilience ${ }^{\mathrm{il}}$ of sub-systems of Earth (Holling 1973, Folke et al. 2004, Gordon et al. 2008) and the Earth System as a whole. Erosion of resilience manifests itself when long periods of seemingly stable conditions are followed by periods of abrupt, non-linear change, reflected in critical transitions from one stability domain to another when thresholds are crossed (Scheffer et al. 2001, Walker et al. 2004, Lenton et al. 2008, Scheffer 2009).

The Anthropocene raises a new question: "What are the non-negotiable planetary preconditions that humanity needs to respect in order to avoid the risk of deleterious or even catastrophic environmental change at continental to global scales?" We make a first attempt at identifying planetary boundaries for key Earth System processes associated with dangerous thresholds, the crossing of which could push the planet out of the desired Holocene state.

\section{INTRODUCING THE CONCEPT OF PLANETARY BOUNDARIES}

Here, thresholds are defined as non-linear transitions in the functioning of coupled humanenvironmental systems (Schellnhuber 2002, Lenton 
Fig. 1. The last glacial cycle of 180 (an indicator of temperature) and selected events in human history. The Holocene is the last 10000 years. Adapted from Young and Steffen (2009).

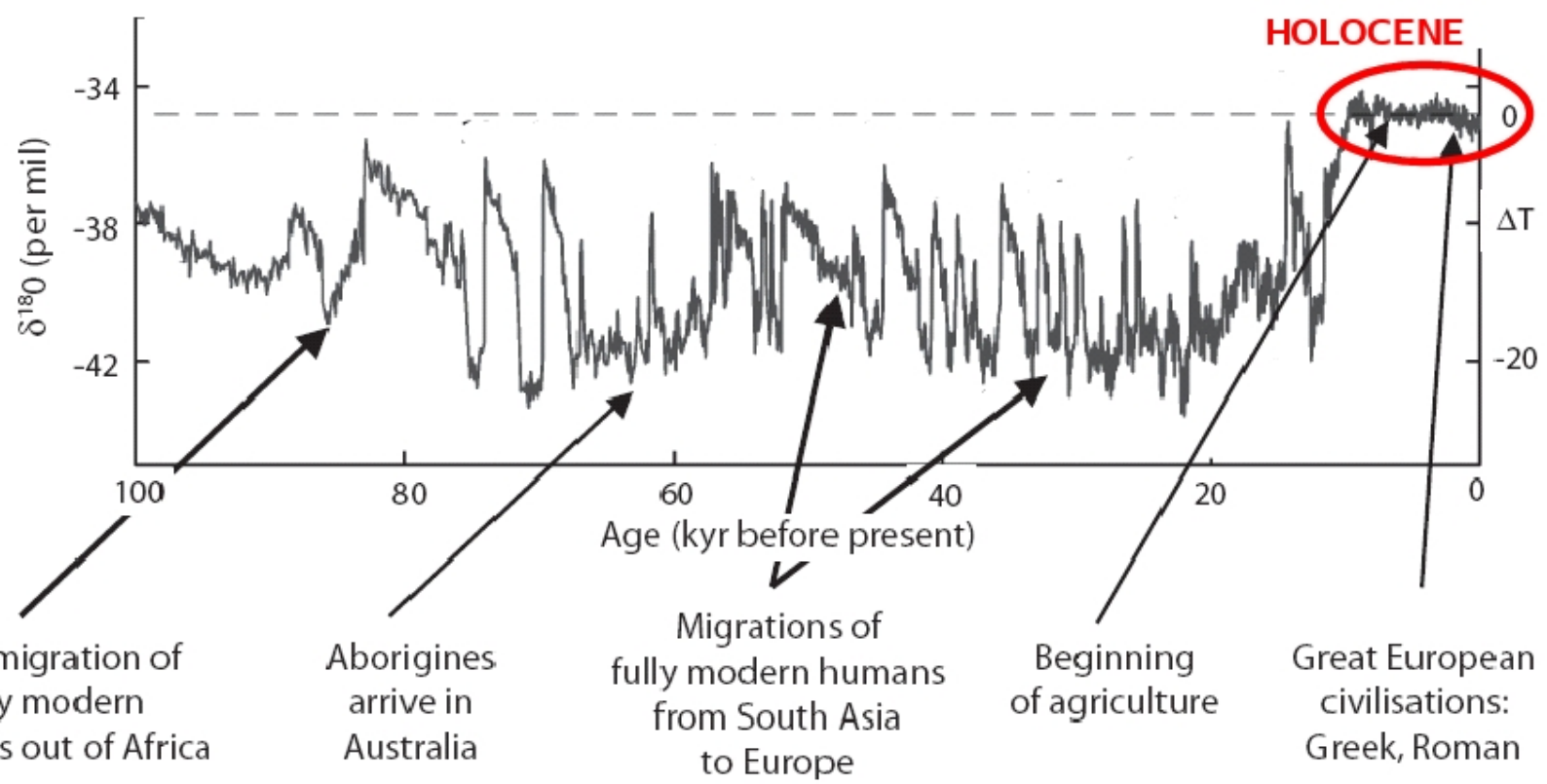

et al. 2008), such as the recent abrupt retreat of Arctic sea ice caused by anthropogenic global warming (Johannessen 2008). Thresholds are intrinsic features of those systems and are often defined by a position along one or more control variables (Fig. 2a), such as temperature and the icealbedo feedback in the case of sea ice. Some Earth System processes, such as land-use change, are not associated with known thresholds at the continental to global scale, but may, through continuous decline of key ecological functions (such as carbon sequestration), cause functional collapses, generating feedbacks that trigger or increase the likelihood of a global threshold in other processes (such as climate change) (Fig. 2b). Such processes may, however, trigger non-linear dynamics at the lower scales (e.g., crossing of thresholds in lakes, forests, and savannahs, as a result of land-use change, water use, and nutrient loading). Such non-linear changes, from a desired to an undesired state, may on aggregate become a global concern for humanity, if occurring across the planet.

Boundaries, on the other hand, are humandetermined values of the control variable set at a "safe" distance from a dangerous level (for processes without known thresholds at the continental to global scales) or from its global threshold. Determining a safe distance involves normative judgments of how societies choose to deal with risk and uncertainty (see Fig. 2a, b). The choice of control variable for each planetary boundary was based on our assessment of the variable that on balance may provide the most comprehensive, aggregated, and measurable parameter for individual boundaries (Appendix 1, Supplementary Methods 1).

Much of the uncertainty in quantifying planetary boundaries is due to our lack of scientific knowledge about the nature of the biophysical thresholds themselves (Appendix 1, Supplementary Discussion 1), the intrinsic uncertainty of how complex systems behave, the ways in which other biophysical processes such as feedback mechanisms interact with the primary control variable, and uncertainty regarding the allowed time of overshoot of a critical control variable in the Earth System before a threshold is crossed. This generates a zone of uncertainty around each threshold (Fig. 2a, b). The 
Fig. 2. Conceptual description of planetary boundaries. In (a) the boundary is designed to avoid the crossing of a critical continental to global threshold in an Earth System process. Insufficient knowledge and the dynamic nature of the threshold generate a zone of uncertainty about its precise position, which informs the determination of where to place the boundary. In (b) there is no global threshold effect as far as we know, but exceeding the boundary level will lead to significant interactions with regional and global thresholds and/or may cause a large number of undesired threshold effects at the local to regional scale, which in aggregate add up to a serious global concern for humanity.
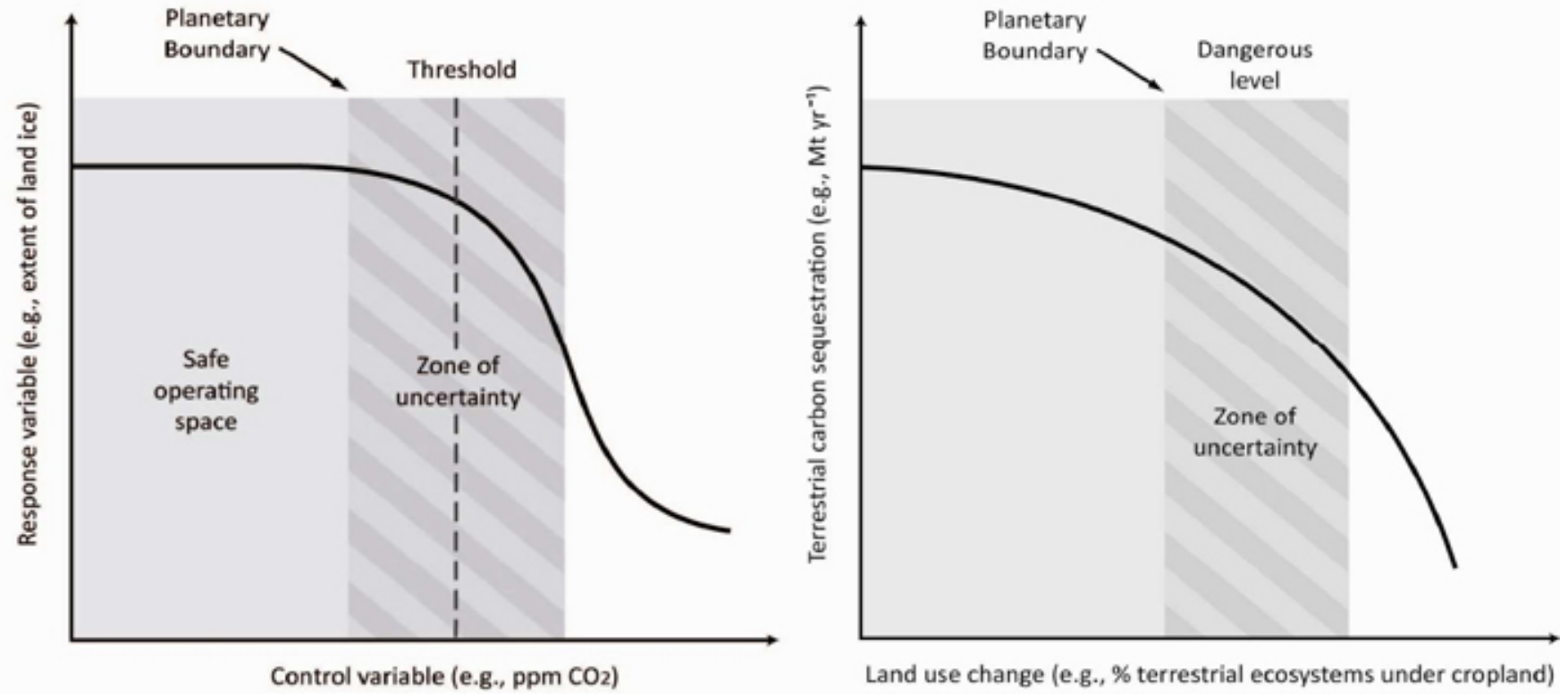

nature and size of that zone is critical in determining where to place the planetary boundary.

We have defined the boundary position to correspond to our assessment of the lower end of the uncertainty zone for each boundary (Figs. 2a,b, $3)$. Each proposed boundary position assumes that no other boundaries are transgressed.

The planetary boundaries approach rests on three branches of scientific inquiry. The first addresses the scale of human action in relation to the capacity of the Earth to sustain it, a significant feature of the ecological economics research agenda (Costanza 1991), drawing on work on the essential role of the life-support environment for human well-being (Odum 1989, Vitousek et al. 1997) and biophysical constraints for the expansion of the economic subsystem (Boulding 1966, Arrow et al. 1995). The second is the work on understanding essential Earth
System processes (Bretherton 1988, Schellnhuber 1999, Steffen et al. 2004), including human actions (Clark and Munn 1986, Turner et al. 1990), brought together in the evolution of global change research toward Earth System science and in the development of sustainability science (Clark and Dickson 2003). The third is the framework of resilience (Holling 1973, Gunderson and Holling 2002, Walker et al. 2004, Folke 2006) and its links to complex dynamics (Kaufmann 1993, Holland 1996) and self-regulation of living systems (Lovelock 1979, Levin 1999), emphasizing multiple basins of attraction and thresholds effects (Scheffer et al. 2001, Folke et al. 2004, Biggs et al. 2009).

Our proposed framework builds on and extends approaches based on limits-to-growth (Meadows et al. 1972, 2004), safe minimum standards (CiriacyWantrup 1952, Bishop 1978, Crowards 1998), the 
Fig. 3. Summary of criteria and process for the identification and definition of planetary boundaries.

Although current scientific understanding underpins the analysis of the existence, location, and nature of thresholds, normative judgments influence the definition and the position of planetary boundaries:

- The selection of planetary boundaries emerges from the definition of what constitutes unacceptable human-induced global environmental change.

- The position of a planetary boundary is a function of the degree of risk the global community is willing to take, e.g., how close to an uncertainty zone around a dangerous level or threshold of a Earth System process humanity is willing to place itself, and/or for how long a boundary can temporarily be transgressed before a threshold is crossed.

- The position is furthermore a function of the social and ecological resilience of the impacted societies (e.g., the ability of coastal communities to cope with sea level rise later this century if a climate-change boundary is transgressed for too long).

- Boundaries are identified for processes where the time needed to trigger an abrupt or irreversible change is within an "ethical time horizon" - a timeframe (i) short enough to influence today's decisions yet long enough to provide the basis for sustainability over many generations to come, and (ii) within which decisions taken can influence whether or not the estimated threshold is crossed.

Having identified boundary candidates among Earth System processes, a set of criteria were considered in identifying appropriate control variables: (i) that the variable is universally applicable for the sub-systems linked to the same boundary, (ii) that it can function as a robust indicator of process change, and (iii) that there are available and reliable data. This means that we have taken a pragmatic approach in the first round of defining the planetary boundary variables, sometimes choosing a parameter of ultimate ecological impact (e.g., rate of extinction of species for biodiversity loss), a proxy indicator (e.g., aragonite saturation state for ocean acidification), or a human drivingforce variable (e.g., $p$ load in the oceans).

precautionary principle (Raffensperger and Tickner 1999), and tolerable windows (WBGU 1995, Petschel-Held et al. 1999) (see Appendix 1, Supplementary Discussion 2). A key advance is that the planetary boundaries approach focuses on the biophysical processes of the Earth System that determine the self-regulating capacity of the planet. It incorporates the role of thresholds related to largescale Earth System processes, the crossing of which may trigger non-linear changes in the functioning of the Earth System, thereby challenging socialecological resilience at regional to global scales. Together, the set of boundaries represents the dynamic biophysical "space" of the Earth System within which humanity has evolved and thrived. The boundaries respect Earth's "rules of the game" or, as it were, define the "planetary playing field" for the human enterprise. The thresholds in key Earth System processes exist irrespective of peoples' preferences, values, or compromises based on political and socioeconomic feasibility, such as expectations of technological breakthroughs and fluctuations in economic growth.

However, choices and actions will to a large extent determine how close we are to the critical thresholds involved, or whether we cross them. Our approach does not offer a roadmap for sustainable 
development; it merely provides, in the context of the human predicament in the Anthropocene, the first step by identifying biophysical boundaries at the planetary scale within which humanity has the flexibility to choose a myriad of pathways for human well-being and development. Further work will need to focus on the societal dynamics that have led to the current situation and propose ways in which our societies can stay within these boundaries.

We have done a comprehensive search for these critical Earth System processes and their associated control variables (see Appendix 1, Supplementary Methods 1). So far, we have been able to identify nine such processes for which boundaries need to be established to minimize the risk of crossing critical thresholds that may lead to undesirable outcomes.

\section{CATEGORIZING PLANETARY BOUNDARIES}

The nine planetary boundaries identified here (Fig. 4) cover the global biogeochemical cycles of nitrogen, phosphorus, carbon, and water; the major physical circulation systems of the planet (the climate, stratosphere, ocean systems); biophysical features of Earth that contribute to the underlying resilience of its self-regulatory capacity (marine and terrestrial biodiversity, land systems); and two critical features associated with anthropogenic global change (aerosol loading and chemical pollution). We assess that there is enough scientific evidence to make a preliminary, first attempt at quantifying control variables for seven of these boundaries (Table 1). The remaining two (aerosol loading and chemical pollution), we believe, should be included among the planetary boundaries, but we are as yet unable to suggest quantitative boundary levels.

We distinguish between boundaries that are directly related to sharp continental or planetary thresholds, such as the risk of melting of the Greenland and Antarctic ice sheets when permanently crossing a threshold of radiative forcing (Lenton et al. 2008, Schellnhuber 2002), and boundaries based on "slow" planetary processes with no current evidence of planetary scale threshold behavior, which provide the underlying resilience of the Earth System by functioning as sinks and sources of carbon and by regulating water, nutrient, and mineral fluxes (Fig. 4).

There is ample evidence from local to regional-scale ecosystems, such as lakes, forests, and coral reefs, that gradual changes in certain key control variables (e.g., biodiversity, harvesting, soil quality, freshwater flows, and nutrient cycles) can trigger an abrupt system state change when critical thresholds have been crossed (Carpenter et al. 2001, Folke et al. 2004, Hughes et al. 2007, Scheffer 2009). More research is urgently needed on the dynamics of thresholds and feedbacks that operate at continental and global scales, especially for slow-changing control variables such as land use and cover, water resource use, rate of biodiversity loss, and nutrient flows. Here, we distinguish between identifiable planetary thresholds driven by systemic globalscale processes (impacting sub-systems "top down") and thresholds that may arise at the local and regional scales, which become a global concern at the aggregate level (if occurring in multiple locations simultaneously) or where the gradual aggregate impacts may increase the likelihood of crossing planetary thresholds in other Earth System processes (thus affecting the Earth System "bottom up") (Fig. 4).

Many planetary-scale processes (such as climate change) primarily produce impacts at a sub-Earth System scale, where such sub-systems show varying degrees of sensitivity to change. For example, climate change is associated with at least nine sub-system "tipping elements" (e.g., the Indian monsoon and El Niño events), which all show varying degrees of sensitivity to a change in radiative forcing or temperature rise (Lenton et al. 2008). We deal with such cross-scale complexity by proposing planetary boundaries to avoid all known sub-Earth System thresholds in the foreseeable future.

\section{QUANTIFYING PLANETARY BOUNDARIES}

In the following, we present the justification and quantifications for the proposed planetary boundaries in Table 1. Extended and additional descriptions for some of the boundaries are available in the supplementary information (Appendix 1, Supplementary Discussion 3-4). 
Fig. 4. Categories of planetary boundaries.

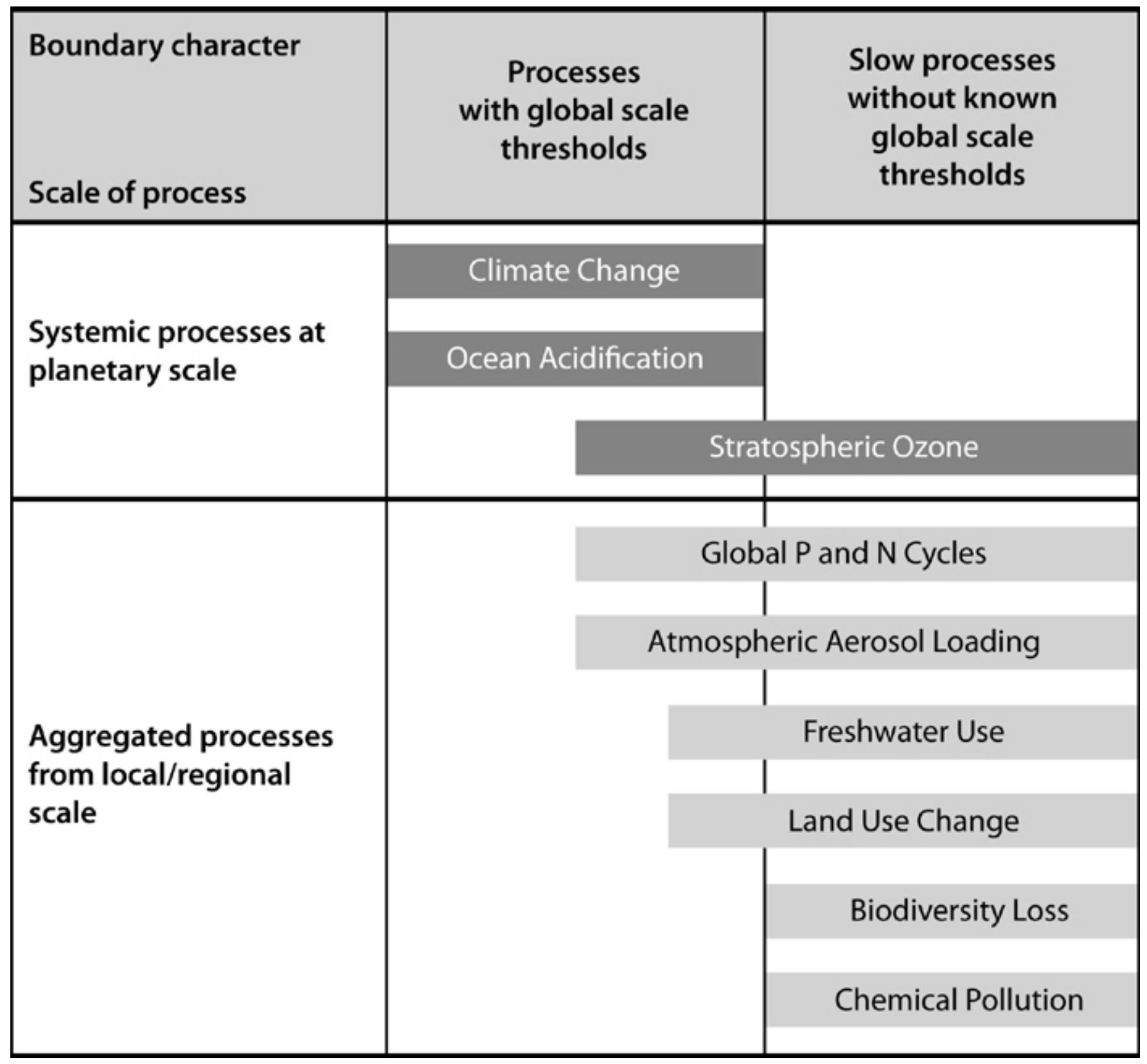

\section{Climate Change}

The climate-change boundary is currently under vigorous discussion as the international community approaches the 15th Conference of the Parties to the UNFCCC in Copenhagen in December 2009. There is a growing convergence toward a " $2{ }^{\circ} \mathrm{C}$ guardrail" approach, that is, containing the rise in global mean temperature to no more than $2{ }^{\circ} \mathrm{C}$ above the preindustrial level. The consideration of this guardrail is based on a combination of analytical and political arguments, taking into account (i) the scientific projections of the respective climate damages to be expected at various levels of global warming, (ii) 
Table 1. Proposed planetary boundaries.

\begin{tabular}{|c|c|c|c|c|}
\hline $\begin{array}{l}\text { Earth System } \\
\text { process }\end{array}$ & Control variable & $\begin{array}{l}\text { Threshold avoided } \\
\text { or influenced by } \\
\text { slow variable }\end{array}$ & $\begin{array}{l}\text { Planetary Boundary } \\
\text { (zone of uncertainty) }\end{array}$ & State of knowledge* \\
\hline $\begin{array}{l}\text { Climate } \\
\text { change }\end{array}$ & $\begin{array}{l}\text { Atmospheric } \mathrm{CO}_{2} \\
\text { concentration, } \\
\text { ppm; } \\
\text { Energy imbalance at } \\
\text { Earth's surface, W } \\
\mathrm{m}^{-2}\end{array}$ & $\begin{array}{l}\text { Loss of polar ice sheets. } \\
\text { Regional climate disruptions. } \\
\text { Loss of glacial freshwater } \\
\text { supplies. } \\
\text { Weakening of carbon sinks. }\end{array}$ & $\begin{array}{l}\text { Atmospheric } \mathrm{CO}_{2} \\
\text { concentration: } 35^{0} \\
\text { ppm } \\
(350-550 \mathrm{ppm}) \\
\text { Energy } \\
\text { imbalance: }+1 \mathrm{~W} \mathrm{~m}^{-2} \\
\left(+1.0-+1.5 \mathrm{~W} \mathrm{~m}^{-2}\right)\end{array}$ & $\begin{array}{l}\text { 1. Ample scientific evidence. } \\
\text { 2. Multiple sub-system } \\
\text { thresholds. } \\
\text { 3. Debate on position of } \\
\text { boundary. }\end{array}$ \\
\hline $\begin{array}{l}\text { Ocean } \\
\text { acidification }\end{array}$ & $\begin{array}{l}\text { Carbonate ion } \\
\text { concentration, } \\
\text { average global } \\
\text { surface ocean } \\
\text { saturation state with } \\
\text { respect to aragonite } \\
\left(\Omega_{\text {arag }}\right)\end{array}$ & $\begin{array}{l}\text { Conversion of coral reefs to } \\
\text { algal-dominated systems. } \\
\text { Regional elimination of some } \\
\text { aragonite- and high- } \\
\text { magnesium calcite-forming } \\
\text { marine biota } \\
\text { Slow variable affecting } \\
\text { marine carbon sink. }\end{array}$ & $\begin{array}{l}\text { Sustain } \geq 80 \% \text { of the } \\
\text { pre-industrial } \\
\text { aragonite saturation } \\
\text { state of mean } \\
\text { surface ocean, } \\
\text { including natural } \\
\text { diel and seasonal } \\
\text { variability } \\
(\geq 80 \%-\geq 70 \%)\end{array}$ & $\begin{array}{l}\text { 1. Geophysical processes well } \\
\text { known. } \\
\text { 2. Threshold likely. } \\
\text { 3. Boundary position uncertain } \\
\text { due to unclear ecosystem } \\
\text { response. }\end{array}$ \\
\hline $\begin{array}{l}\text { Stratospheric } \\
\text { ozone } \\
\text { depletion }\end{array}$ & $\begin{array}{l}\text { Stratospheric } \mathrm{O}_{3} \\
\text { concentration, DU }\end{array}$ & $\begin{array}{l}\text { Severe and irreversible UV- } \\
\text { B radiation effects on human } \\
\text { health and ecosystems. }\end{array}$ & $\begin{array}{l}<5 \% \text { reduction from } \\
\text { pre-industrial level } \\
\text { of } 290 \mathrm{DU} \\
(5 \%-10 \%)\end{array}$ & $\begin{array}{l}\text { 1. Ample scientific evidence. } \\
\text { 2. Threshold well established. } \\
\text { 3. Boundary position implicitly } \\
\text { agreed and respected. }\end{array}$ \\
\hline $\begin{array}{l}\text { Atmospheric } \\
\text { aerosol } \\
\text { loading }\end{array}$ & $\begin{array}{l}\text { Overall particulate } \\
\text { concentration in the } \\
\text { atmosphere, on a } \\
\text { regional basis }\end{array}$ & $\begin{array}{l}\text { Disruption of monsoon } \\
\text { systems. } \\
\text { Human-health effects. } \\
\text { Interacts with climate change } \\
\text { and freshwater boundaries. }\end{array}$ & To be determined & $\begin{array}{l}\text { 1. Ample scientific evidence. } \\
\text { 2. Global threshold behavior } \\
\text { unknown. } \\
\text { 3. Unable to suggest boundary } \\
\text { yet. }\end{array}$ \\
\hline $\begin{array}{l}\text { Biogeo- } \\
\text { chemical } \\
\text { flows: } \\
\text { interference } \\
\text { with P and N } \\
\text { cycles }\end{array}$ & $\begin{array}{l}\text { P: inflow of } \\
\text { phosphorus to } \\
\text { ocean, increase } \\
\text { compared with } \\
\text { natural background } \\
\text { weathering } \\
\mathrm{N} \text { : amount of } \mathrm{N}_{2} \\
\text { removed from } \\
\text { atmosphere for } \\
\text { human use, Mt } \mathrm{N}_{\mathrm{yr}^{-1}}\end{array}$ & $\begin{array}{l}\text { P: avoid a major oceanic } \\
\text { anoxic event (including } \\
\text { regional), with impacts on } \\
\text { marine ecosystems. } \\
\text { N: slow variable affecting } \\
\text { overall resilience of } \\
\text { ecosystems via acidification } \\
\text { of terrestrial ecosystems and } \\
\text { eutrophication of coastal and } \\
\text { freshwater systems. }\end{array}$ & $\begin{array}{l}\mathrm{P}:<10 \times(10 \times- \\
100 \times) \\
\mathrm{N}: \text { Limit industrial } \\
\text { and agricultural } \\
\text { fixation of } \mathrm{N}_{2} \text { to } 35 \\
\text { Mt } \mathrm{N} \text { yr }{ }^{-1}, \text { which is } ~ \\
25 \% \text { of the total } \\
\text { amount of } \mathrm{N}_{2} \text { fixed } \\
\text { per annum naturally } \\
\text { by terrestrial } \\
\text { ecosystems } \\
(25 \%-35 \%)\end{array}$ & $\begin{array}{l}\text { P: (1) Limited knowledge on } \\
\text { ecosystem responses; (2) High } \\
\text { probability of threshold but } \\
\text { timing is very uncertain; (3) } \\
\text { Boundary position highly } \\
\text { uncertain. } \\
\text { N: (1) Some ecosystem } \\
\text { responses known; (2) Acts as a } \\
\text { slow variable, existence of } \\
\text { global thresholds unknown; (3) } \\
\text { Boundary position highly } \\
\text { uncertain. }\end{array}$ \\
\hline $\begin{array}{l}\text { Global } \\
\text { freshwater use }\end{array}$ & $\begin{array}{l}\text { Consumptive blue } \\
\text { water use, } \mathrm{km}^{3} \mathrm{yr}^{-1}\end{array}$ & $\begin{array}{l}\text { Could affect regional climate } \\
\text { patterns (e.g., monsoon } \\
\text { behavior). } \\
\text { Primarily slow variable } \\
\text { affecting moisture feedback, } \\
\text { biomass production, carbon } \\
\text { uptake by terrestrial systems } \\
\text { and reducing biodiversity }\end{array}$ & $\begin{array}{l}<4000 \mathrm{~km}^{3} \mathrm{yr}^{-1} \\
\left(4000-6000 \mathrm{~km}^{3}\right. \\
\left.\mathrm{yr}^{-1}\right)\end{array}$ & $\begin{array}{l}\text { 1. Scientific evidence of } \\
\text { ecosystem response but } \\
\text { incomplete and fragmented. } \\
\text { 2. Slow variable, regional or } \\
\text { subsystem thresholds exist. } \\
\text { 3. Proposed boundary value is a } \\
\text { global aggregate, spatial } \\
\text { distribution determines regional } \\
\text { thresholds }\end{array}$ \\
\hline
\end{tabular}


Land-system Percentage of global Trigger of irreversible and change land cover converted to cropland biomes to undesired states.

Rate of biodiversity loss

Extinction rate, extinctions per million species per year (E/MSY)

Chemical pollution
For example, emissions, concentrations, or effects on ecosystem and Earth System functioning of persistent organic pollutants (POPs), plastics, endocrine disruptors, heavy metals, and nuclear wastes.
Primarily acts as a slow variable affecting carbon storage and resilience via changes in biodiversity and landscape heterogeneity free land surface

Slow variable affecting ecosystem functioning at continental and ocean basin scales.

Impact on many other boundaries- $\mathrm{C}$ storage, freshwater, $\mathrm{N}$ and $\mathrm{P}$ cycles, land systems. Massive loss of biodiversity unacceptable for ethical reasons.

Thresholds leading to unacceptable impacts on human health and ecosystem functioning possible but largely unknown.

May act as a slow variable undermining resilience and increase risk of crossing other thresholds. $\leq 15 \%$ of global iceconverted to cropland (15\%20\%)

$<10 \mathrm{E} / \mathrm{MSY}$

1. Ample scientific evidence of impacts of land-cover change on ecosystems, largely local and regional.

2. Slow variable, global threshold unlikely but regional thresholds likely.

3. Boundary is a global aggregate with high uncertainty, regional distribution of land-system change is critical.

\section{Incomplete knowledge on the role of biodiversity for ecosystem functioning across scales. \\ 2. Thresholds likely at local and regional scales. 3 . Boundary position highly uncertain.}

To be determined

1. Ample scientific evidence on individual chemicals but lacks an aggregate, global-level analysis.

2. Slow variable, large-scale thresholds unknown. 3. Unable to suggest boundary yet. value judgments on the (non-) acceptability of such impacts, and (iii) political considerations of what is perceived as a realistic target given the predicament humanity is facing today due to already committed global warming. It needs to be emphasized, however, that significant risks of deleterious climate impacts for society and the environment have to be faced even if the $2^{\circ} \mathrm{C}$ line can be held (Richardson et al. 2009).

The approach we present here of defining a climatechange boundary (described below) is based on our scientific understanding of what is required to avoid the crossing of critical thresholds that separate qualitatively different climate system states. As a matter of fact, the boundary so identified gives a high probability that the $2^{\circ} \mathrm{C}$ guardrail is also respected (Hare and Meinshausen 2006).
The climate-change boundary proposed here aims at minimizing the risk of highly non-linear, possibly abrupt and irreversible, Earth System responses (National Research Council (NRC) 2002, IPCC $2007 \mathrm{~b}$ ) related to one or more thresholds, the crossing of which could lead to the disruption of regional climates (Lenton et al. 2008), trigger the collapse of major climate dynamics patterns such as the thermohaline circulation (Clark et al. 2002), and drive other impacts difficult for society to cope with, such as rapid sea-level rise. The risk of crossing such thresholds will rise sharply with further anthropogenically driven deviation from the natural variability of the Holocene climate.

We propose a dual approach to defining the planetary boundary for climate change, using both atmospheric $\mathrm{CO}_{2}$ concentration and radiative 
forcing as global-scale control variables. We suggest boundary values of $350 \mathrm{ppm} \mathrm{CO}_{2}$ and $1 \mathrm{~W}$ $\mathrm{m}^{-2}$ above the pre-industrial level, respectively. The boundary is based on (i) an analysis of the equilibrium sensitivity of the climate system to greenhouse gas forcing, (ii) the behavior of the large polar ice sheets under climates warmer than those of the Holocene (Hansen et al. 2008), and (iii) the observed behavior of the climate system at a current $\mathrm{CO}_{2}$ concentration of about $387 \mathrm{ppm}$ and $+1.6 \mathrm{~W}$ $\mathrm{m}^{-2}\left(+0.8 /-1.0 \mathrm{~W} \mathrm{~m}^{-2}\right)$ net radiative forcing (IPCC 2007a).

Climate sensitivity, as estimated by the current suite of climate models, includes only "fast feedbacks" such as changes in water vapor, clouds, and sea ice, and yields a value of $\sim 3^{\circ} \mathrm{C}$ (range: $2-4.5^{\circ} \mathrm{C}$ ) for a doubling of atmospheric $\mathrm{CO}_{2}$ concentration above pre-industrial levels (IPCC 2007a). Inclusion of "slow feedbacks" such as decreased ice sheet volume, changed vegetation distribution, and inundation of continental shelves, gives an estimated climate sensitivity of $\sim 6^{\circ} \mathrm{C}$ (range: $4-8^{\circ}$ C) (Hansen et al. 2008). Thus, the current suite of climate models may significantly underestimate the severity of long-term future climate change for a given concentration of greenhouse gases.

Palaeo-climatic data from 65 million years ago to the present points to decreasing $\mathrm{CO}_{2}$ concentration as the major factor in the long-term cooling trend over that period. The data further suggest that the planet was largely ice free until atmospheric $\mathrm{CO}_{2}$ concentrations fell to $450 \mathrm{ppm}( \pm 100 \mathrm{ppm})$, indicating a danger zone when concentrations of $\mathrm{CO}_{2}$ rise within the range of 350-550 ppm (Hansen et al. 2008). Despite uncertainties related to the degree of hysteresis in the relationship between ice growth and ice creation in response to temperature change, the above suggests that raising $\mathrm{CO}_{2}$ concentration above $350 \mathrm{ppm}$ may lead to crossing a threshold that results in the eventual disappearance of some of the large polar ice sheets, with a higher risk of crossing the threshold as the $\mathrm{CO}_{2}$ concentration approaches the upper end of the range.

The contemporary climate is thus moving out of the envelope of Holocene variability, sharply increasing the risk of dangerous climate change. Observations of a climate transition include a rapid retreat of summer sea ice in the Arctic Ocean (Johannessen 2008), retreat of mountain glaciers around the world (IPCC 2007a), loss of mass from the Greenland and West Antarctic ice sheets (Cazenave 2006), an increased rate of sea-level rise in the last 10-15 years (Church and White 2006), a $4^{\circ}$ latitude pole-ward shift of subtropical regions (Seidel and Randel 2006), increased bleaching and mortality in coral reefs (Bellwood et al. 2004, Stone 2007), a rise in the number of large floods (Milly et al. 2002, MEA 2005a), and the activation of slow feedback processes like the weakening of the oceanic carbon sink (Le Quéré et al. 2007).

The present equivalence of the boundary for $\mathrm{CO}_{2}$ and net radiative forcing arises because the cooling effect of aerosols counteracts the warming effect of non- $\mathrm{CO}_{2}$ greenhouse gases (IPCC 2007a, Ramanathan and Feng 2008). However, these non$\mathrm{CO}_{2}$ forcings could change in future, necessitating an adjustment to the $\mathrm{CO}_{2}$ boundary.

\section{Ocean Acidification}

Ocean acidification poses a challenge to marine biodiversity and the ability of oceans to continue to function as a sink of $\mathrm{CO}_{2}$ (currently removing roughly $25 \%$ of human emissions). The atmospheric removal process includes both dissolution of $\mathrm{CO}_{2}$ into seawater, and the uptake of carbon by marine organisms. The ocean absorption of anthropogenic $\mathrm{CO}_{2}$ is not evenly distributed spatially (Sabine et al. 2004) or temporally (Canadell et al. 2007).

Addition of $\mathrm{CO}_{2}$ to the oceans increases the acidity (lowers $\mathrm{pH}$ ) of the surface seawater. Many marine organisms are very sensitive to changes in ocean $\mathrm{CO}_{2}$ chemistry-especially those biota that use carbonate ions dissolved in the seawater to form protective calcium carbonate shells or skeletal structures. Surface ocean $\mathrm{pH}$ has decreased by about $0.1 \mathrm{pH}$ units (corresponding to a $30 \%$ increase in hydrogen ion concentration and a $16 \%$ decline in carbonate concentrations) since pre-industrial times (Guinotte et al. 2003, Feely et al. 2004, Orr et al. 2005, Guinotte and Fabry 2008, Doney et al. 2009). This rate of acidification is at least 100 times faster than at any other time in the last 20 million years.

Marine organisms secrete calcium carbonate primarily in the forms of aragonite (which is produced by corals, many mollusks, and other marine life) and calcite (which is produced by different single-celled plankton and other groups). Aragonite is about $50 \%$ more soluble in seawater than calcite (Mucci 1983). Thus, with rising ocean 
acidity, aragonite shells are expected to dissolve before those made of calcite unless the organism has evolved some mechanism to prevent shell dissolution. A third type of biogenic calcium carbonate, high magnesium calcite, is secreted by some marine life such as coralline red algae and sea urchins. Depending on its magnesium concentration, high magnesium calcite can be more soluble in seawater than aragonite. For all three of these types of calcium carbonate, the carbonate ion concentration strongly affects the saturation state of the mineral in seawater. If the $\mathrm{pH}$ of the oceans decreases sufficiently, the concomitant reduction in carbonate ion concentration results in a decrease in the seawater saturation state with respect to either aragonite or calcite. If the calcium carbonate saturation state is less than one, then calcium carbonate produced by marine organisms to make their solid shells becomes soluble unless the organism has some way of preventing dissolution (Feely et al. 2004, Fabry et al. 2008).

Globally, the surface ocean aragonite saturation state $\left(\Omega_{\text {arag }}\right)$ is declining with rising ocean acidity. It has fallen from a pre-industrial value of $\Omega_{\text {arag }}=$ 3.44 to a current value of 2.9. A $\Omega_{\text {arag }}$ value of 2.29 is projected for a doubling of $\mathrm{CO}_{2}$ (Guinotte and Fabry 2008). Even though globally averaged $\Omega_{\text {arag }}$ values in surface waters remain above unity for a doubling of atmospheric $\mathrm{CO}_{2}$, large parts of the Southern Ocean and the Arctic Ocean are projected to become undersaturated with respect to aragonite as early as 2030-2060 (Orr et al. 2005, McNeil and Matear 2008, Steinacher et al. 2009). Aragonite undersaturation means that these waters will become corrosive to the aragonite and highmagnesium calcite shells secreted by a wide variety of marine organisms. The projected rate of change in ocean $\mathrm{CO}_{2}$ chemistry leaves little time for organisms to evolve adaptations. Although some species may be $\mathrm{CO}_{2}$ insensitive or able to adapt (e. g., Miller et al. 2009), the energetic costs of achieving net shell growth and preventing dissolution in conditions of aragonite undersaturation will likely have other impacts on overall growth rates, predation, metabolism, or reproduction, as observed in organisms from other regions (e.g., Iglesias-Rodriguez et al. 2008, Fabry et al. 2008, Wood et al. 2008, Tunnicliffe et al. 2009).

The large-scale depletion of aragonite-forming organisms would be a major disturbance in marine ecosystems, the consequences and impacts of which are highly uncertain. Deleterious effects on many marine organisms start well above the geochemical threshold of $\Omega_{\text {arag }}=1$, with calcification rates for some organisms being reduced by $10 \%-60 \%$ for a doubling of atmospheric $\mathrm{CO}_{2}$ (Guinotte and Fabry 2008, Fabry et al. 2008). Even small sensitivities of biota to increased $\mathrm{CO}_{2}$ will become amplified over successive generations and may drive the restructuring of diverse marine ecosystems, the consequences of which are very difficult to predict (Fabry 2008). Furthermore, by the year 2200, under a business-as-usual scenario for fossil-fuel consumption, the reduction in seawater $\mathrm{pH}$ and phytoplankton could induce a large reduction in the export of marine organic matter from coastal waters leading to considerable expansion of hypoxic zones (Hofmann and Schellnhuber 2009).

Ocean acidification may have serious impacts on coral reefs and associated ecosystems. Coral reefs are in danger of being exposed to marginal conditions $\left(\Omega_{\text {arag }}\right.$ values between $\left.3-3.5\right)$ or extremely marginal conditions $\left(\Omega_{\text {arag }}\right.$ values below 3 ) almost everywhere by as early as 2050 (Kleypas et al. 1999, Guinotte et al. 2003, Langdon and Atkinson 2005, Hoegh-Guldberg et al. 2007), causing substantial changes in species composition and in the dynamics of coral and other reef communities (Kuffner et al. 2008, Guinotte and Fabry 2008, Doney et al. 2009). Similarly, marine plankton are also vulnerable (Riebesell et al. 2000), presumably with ripple effects up the food chain. Ocean acidification and warming combine and interact to decrease the productivity in coral reefs (Anthony et al. 2008), reinforcing the notion that multiple stressors on coral reefs often combine to have negative effects that are well beyond those expected from any single stressor (Bellwood et al. 2004).

Although the threshold for aragonite saturation is easy to define and quantify, significant questions remain as to how far from this threshold the boundary value should be set. Combining estimates of the point at which calcification rates begin to be affected substantially, the values of aragonite saturation state at which conditions for corals go from adequate to marginal, and the point at which surface waters at high latitudes begin to approach aragonite undersaturation suggests a placement of the ocean acidification boundary well away from the aragonite saturation state at dissolution $\left(\Omega_{\text {arag }}=\right.$ 1). As a first estimate, we propose a planetary boundary where oceanic aragonite saturation state is maintained at $80 \%$ or higher of the average global 
pre-industrial surface seawater $\Omega_{\text {arag }}$ of 3.44 . Recognizing that carbonate chemistry can be variable over diel and seasonal timescales (Tyrrell et al. 2008, Feely et al. 2008, Miller et al. 2009), we suggest that the typical diel and seasonal range of values of aragonite saturation state be incorporated into this boundary (i.e., $>80 \%$ of the average surface ocean, pre-industrial aragonite saturation state \pm diel and seasonal variability). The major rationale behind this subjective value is twofold: to keep highlatitude surface waters above aragonite undersaturation and to ensure adequate conditions for most coral systems.

\section{Stratospheric Ozone Depletion}

Stratospheric ozone filters ultraviolet radiation from the sun. The appearance of the Antarctic ozone hole was a textbook example of a threshold in the Earth System being crossed-completely unexpectedly. A combination of increased concentrations of anthropogenic ozone-depleting substances (like chlorofluorocarbons) and polar stratospheric clouds moved the Antarctic stratosphere into a new regime: one in which ozone effectively disappeared in the lower stratosphere in the region during the Austral spring. This thinning of the Austral polar stratospheric ozone layer has negative impacts on marine organisms (Smith et al. 1992) and poses risks to human health. Although it does not appear that there is a similar threshold for global ozone, there is the possibility that global warming (which leads to a cooler stratosphere) could cause an increase in the formation of polar stratospheric clouds. Were this to happen in the Arctic region, it could trigger ozone holes over the northern hemisphere continents, with potential impacts on populations there.

Although the ozone hole phenomenon is a classic example of a threshold, we have chosen to frame the planetary boundary around extra-polar stratospheric ozone. There are two main reasons for this framing. First, the ozone hole "tipping point" depends on anthropogenic ozone-depleting substances, but also on sufficiently cold temperatures and a sufficient amount of water vapor and, in some cases, nitric acid. Humans contribute directly to the first (and to some extent the last) of these, and indirectly to the others. Second, although polar ozone holes have local impacts, a thinning of the extra-polar ozone layer would have a much larger impact on humans and ecosystems.
In the case of global, extra-polar stratospheric ozone, there is no clear threshold around which to construct a boundary. As such, the placement of our boundary in this case is of necessity more uncertain than, for example, in the case of ocean acidification. We consider the planetary boundary for ozone levels to be a $<5 \%$ decrease in column ozone levels for any particular latitude with respect to 1964-1980 values (Chipperfield et al. 2006).

Fortunately, because of the actions taken as a result of the Montreal Protocol (and its subsequent amendments), we appear to be on a path that avoids transgression of this boundary. In 2005, the tropospheric concentrations of ozone-depleting gases had decreased by 8\%-9\% from their peak values in 1992-1994 (Clerbaux et al. 2006). Although there is a considerable lag time between concentration decreases in the troposphere and stratospheric ozone recovery, at least the major anthropogenic driver of ozone depletion is being reduced. The decline in stratospheric ozone concentrations between $60^{\circ} \mathrm{S}$ and $60^{\circ} \mathrm{N}$ seen since the 1990s has been halted (Chipperfield et al. 2006). However, the Antarctic ozone hole is expected to exist for some decades, and Arctic ozone losses may continue for the next decade or two. On balance, the case of stratospheric ozone is a good example where concerted human effort and wise decision making seem to have enabled us to stay within a planetary boundary.

\section{Interference with the Global Phosphorus and Nitrogen Cycles}

Local to regional-scale anthropogenic interference with the nitrogen cycle and phosphorus flows has induced abrupt shifts in lakes (Carpenter 2005) and marine ecosystems (e.g., anoxia in the Baltic sea) (Zillén et al. 2008). Eutrophication due to humaninduced influxes of nitrogen $(\mathrm{N})$ and phosphorus $(\mathrm{P})$ can push aquatic and marine systems across thresholds, generating abrupt non-linear change from, for example, a clear-water oligotrophic state to a turbid-water eutrophic state (Carpenter et al. 1999). Shifts between such alternate stable states depend on complex interactions between $\mathrm{N}$ and $\mathrm{P}$ flows and on the prevailing biogeochemical setting. Human-induced degradation of ecosystem states (e. g., overfishing, land degradation) and increase in $\mathrm{N}$ and $\mathrm{P}$ flows at regional to global scales may cause undesired non-linear change in terrestrial, aquatic, and marine systems, while simultaneously 
functioning as a slow driver influencing anthropogenic climate change at the planetary level.

We cannot exclude the possibility that the $\mathrm{N}$ and $\mathrm{P}$ cycles should, in fact, be separate planetary boundaries in their own right. They both influence, in complex and non-linear ways, human life-support systems at regional scales, and both have significant aggregate planetary impacts, which makes them key processes of the Anthropocene. The reason to keep them as one boundary in this paper is primarily the close interactions between $\mathrm{N}$ and $\mathrm{P}$ as key biological nutrients in driving abrupt shifts in sub-systems of the Earth.

Human modification of the $\mathrm{N}$ cycle is profound (Galloway and Cowling 2002, Gruber and Galloway 2008). Human activities now convert more $\mathrm{N}_{2}$ from the atmosphere into reactive forms than all of the Earth's terrestrial processes combined. Human-driven conversion occurs primarily through four processes: industrial fixation of atmospheric $\mathrm{N}_{2}$ to ammonia ( $\left.80 \mathrm{Mt} \mathrm{N} \mathrm{yr}^{-1}\right)$; agricultural fixation of atmospheric $\mathrm{N}_{2}$ via cultivation of leguminous crops ( 40 $\left.\mathrm{Mt} \mathrm{N} \mathrm{yr}^{-1}\right)$; fossil-fuel combustion ( $\left.20 \mathrm{Mt} \mathrm{N} \mathrm{yr}^{-1}\right)$; and biomass

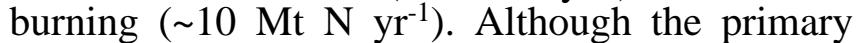
purpose of most of this new reactive $\mathrm{N}$ is to enhance food production via fertilization, much reactive $\mathrm{N}$ eventually ends up in the environment-polluting waterways and coastal zones, adding to the local and global pollution burden in the atmosphere, and accumulating in the biosphere. Efforts to limit $\mathrm{N}$ pollution have, to date, been undertaken at local and regional scales only - for example, by limiting the concentration of nitrate in groundwater or the emission of nitric oxides to urban airsheds.

At the global scale, the addition of various forms of reactive $\mathrm{N}$ to the environment acts primarily as a slow variable, eroding the resilience of important sub-systems of the Earth System. The exception is nitrous oxide, which is one of the most important greenhouse gases and thus acts as a systemic driver at the planetary scale. Nitrous oxide is included in the climate-change boundary by applying radiative forcing (maximum $+1 \mathrm{~W} \mathrm{~m}^{-2}$ of anthropogenic forcing) as the control variable.

For the other forms of reactive $\mathrm{N}$, setting a planetary boundary is not straightforward. The simplest and most direct approach is to consider the human fixation of $\mathrm{N}_{2}$ from the atmosphere as a giant valve that controls a massive flow of new reactive $\mathrm{N}$ into the Earth System. The boundary can then be set by using that valve to control the amount of additional reactive $\mathrm{N}$ flowing into the Earth System. We suggest that the boundary initially be set at approximately $25 \%$ of its current value, or to about $35 \mathrm{Mt} \mathrm{N} \mathrm{yr}^{-1}$. We emphasize that this is a first guess only. Much more research and synthesis of information is required to enable a more informed boundary to be determined.

Even this initial boundary would greatly reduce the amount of reactive $\mathrm{N}$ pushed into land, ocean, and atmospheric systems. It would eliminate the current flux of $\mathrm{N}$ onto the land and could trigger much more efficient and less polluting ways of enhancing food production. It would almost surely also trigger the return of $\mathrm{N}$ in human effluent back onto productive landscapes, thus further reducing the leakage of reactive $\mathrm{N}$ into ecosystems.

Although $\mathrm{N}$ forms part of a biological global cycle, $\mathrm{P}$ is a finite fossil mineral mined for human use and added naturally into the Earth System through geological weathering processes. The crossing of a critical threshold of $\mathrm{P}$ inflow to the oceans has been suggested as the key driver behind global-scale ocean anoxic events (OAE), potentially explaining past mass extinctions of marine life (Handoh and Lenton 2003). The dynamics between bi-stable oxic and anoxic conditions is believed to be induced by positive feedbacks between anoxia, $\mathrm{P}$ recycling from sediments, and marine productivity.

Modeling suggests that a sustained increase of $\mathrm{P}$ inflow to the oceans exceeding $20 \%$ of the natural background weathering rate could have been enough to induce past OAEs (Handoh and Lenton 2003). Assuming a relatively low estimate of "preagricultural" $\mathrm{P}$ input to the oceans of $1.1 \mathrm{Mt} \mathrm{yr}^{-1}$ (3.5 E10 mol $\left.\mathrm{P} \mathrm{yr}^{-1}\right)$, this increased inflow corresponds to only 225,000 tonnes $\mathrm{P} \mathrm{yr}^{-1}\left(0.72 \mathrm{E} 10 \mathrm{~mol} \mathrm{P} \mathrm{yr}^{-1}\right)$. Of the global human extraction of $\sim 20 \mathrm{Mt} \mathrm{yr}^{-1}$ of P, an estimated $10.5 \mathrm{Mt} \mathrm{yr}^{-1}$ is lost from the world's cropland, the primary source of $\mathrm{P}$ inflow to the oceans. The increase of reactive $P$ to the oceans from human activities has been estimated (year 2000) at $\sim 9 \mathrm{Mt} \mathrm{yr}^{-1}$ (8.5-9.5 $\mathrm{Mt} \mathrm{yr}^{-1}$ depending on how detergent and sewage effluent fluxes are handled) (Mackenzie et al. 2002). Despite a substantial increase in anthropogenic P inflow to oceans (up to 8-9 times higher than the natural background rate), it remains highly uncertain whether and, if so, when anthropogenic $\mathrm{P}$ inflow could reach a point where a human-induced OAE would be triggered. For the 
global deep ocean to shift to an anoxic state requires strong recycling of $\mathrm{P}$ from sediments as bottom waters become more anoxic, thus fuelling increased productivity and amplifying the initial change in a positive feedback loop. In existing models, the resulting dynamics have a 10 000-year timescale due to the long residence time of deep ocean $\mathrm{P}$ (Lenton et al. 2008). Furthermore, even though humans have greatly accelerated the inflow of $\mathrm{P}$ to the oceans, it would still take in the order of 10000 years to double $\mathrm{P}$ in the oceans. This suggests that for humans to trigger an OAE should still be over 1000 years away, thus shifting it down the list in our current sphere. Our tentative modeling analyses, using the model by Handoh and Lenton (2003), show that a 10 -fold increase of $\mathrm{P}$ inflow to the oceans (i.e., slightly higher than the current level), if sustained for 1000 years, would raise the anoxic fraction of the ocean from 0.14 to 0.22 . Current estimates of available phosphate rock reserves (up to $20 \mathrm{Gt}$ of P) suggest that such an input could not be sustained for more than 1000 years. Even if P inflows were then returned to pre-industrial levels, the anoxic fraction would continue to rise for another 1000 years. However, a complete OAE (anoxic fraction of 1) would be avoided. It is uncertain what qualitative changes and regional state changes such a sustained inflow would trigger, however, current evidence suggests that it would induce major state changes at local and regional levels, including widespread anoxia in some coastal and shelf seas.

There are very large uncertainties in these analyses, due to the complex interactions between oxicanoxic states, different forms of $\mathrm{P}$ in marine systems, and interactions between abiotic and biotic conditions in the oceans (not least driven by the other planetary boundaries of ocean acidification, $\mathrm{N}$ inflow, marine biodiversity, and climate change). Hence it is difficult to precisely quantify a planetary boundary of $\mathrm{P}$ inflow to the oceans that places humanity at a safe distance from triggering deleterious, widespread ocean anoxia. The problem is partly one of defining what is deleterious, given (current) observations of abrupt P-induced regional anoxic events.

We suggest that, at the very least, a boundary level should be set that (with current knowledge) allows humanity to safely steer away from the risk of triggering an OAE even over longer time horizons (>1000 years). This in turn may require that anthropogenic $\mathrm{P}$ inflow to the ocean is not allowed to exceed a human-induced level of $~ 10$ times the natural background rate of $\sim 1 \mathrm{Mt} \mathrm{P} \mathrm{yr}^{-1}$. This is higher than the proposed trigger rate of past OAEs, but a level that is believed to create a safe long-term (over centuries) global operating space. The proposed planetary boundary for anthropogenic $\mathrm{P}$ inflow to the oceans is thus tentatively placed at $<10$ times $(<10 \times)$ the natural background weathering flux of $P$, with an equally tentative uncertainty range $(<10 x-<100 x)$.

\section{Rate of Biodiversity Loss}

Like land-system change (see below), local and regional biodiversity changes can have pervasive effects on Earth System functioning and interact with several other planetary boundaries. For example, loss of biodiversity can increase the vulnerability of terrestrial and aquatic ecosystems to changes in climate and ocean acidity, thus reducing the safe boundary levels for these processes.

The current and projected rates of biodiversity loss constitute the sixth major extinction event in the history of life on Earth-the first to be driven specifically by the impacts of human activities on the planet (Chapin et al. 2000). Previous extinction events, such as the Tertiary extinction of the dinosaurs and the rise of mammals, caused massive permanent changes in the biotic composition and functioning of Earth's ecosystems. This suggests non-linear and largely irreversible consequences of large-scale biodiversity loss.

Accelerated biodiversity loss during the Anthropocene (Mace et al. 2005) is particularly serious, given growing evidence of the importance of biodiversity for sustaining ecosystem functioning and services and for preventing ecosystems from tipping into undesired states (Folke et al. 2004). A diversity of functional response mechanisms to environmental variation among species in an ecosystem maintains resilience to disturbances. Consequently, ecosystems (both managed and unmanaged) with low levels of response diversity within functional groups are particularly vulnerable to disturbances (such as disease) and have a greater risk of undergoing catastrophic regime shifts (Scheffer and Carpenter 2003).

Species play different roles in ecosystems, in the sense of having different effects on ecosystem 
processes and/or different responses to shifts in the physical or biotic environment (i.e., they occupy different niches). Species loss, therefore, affects both the functioning of ecosystems and their potential to respond and adapt to changes in physical and biotic conditions (Elmqvist et al. 2003, Suding et al. 2008).

Currently, the global extinction rate far exceeds the rate of speciation, and consequently, loss of species is the primary driver of changes in global biodiversity. The average extinction rate for marine organisms in the fossil record is 0.1 to 1 extinctions per million species-years (E/MSY), and extinction rates of mammals in the fossil record also fall within this range (Pimm et al. 1995, Mace et al. 2005). Accelerated species loss is increasingly likely to compromise the biotic capacity of ecosystems to sustain their current functioning under novel environmental and biotic circumstances (Walker et al. 1999).

Since the advent of the Anthropocene, humans have increased the rate of species extinction by 100-1000 times the background rates that were typical over Earth's history (Mace et al. 2005), resulting in a current global average extinction rate of $\geq 100 \mathrm{E} /$ MSY. The average global extinction rate is projected to increase another 10-fold, to 100010000 E/MSY during the current century (Mace et al. 2005). Currently about $25 \%$ of species in wellstudied taxonomic groups are threatened with extinction (ranging from $12 \%$ for birds to $52 \%$ for cycads). Until recently, most extinctions (since 1500) occurred on oceanic islands. In the last 20 years, however, about half of the recorded extinctions have occurred on continents, primarily due to land-use change, species introductions, and increasingly climate change, indicating that biodiversity is now broadly at risk throughout the planet.

The lower and upper bounds of extinction rates in the fossil record $(0.1-1.0 \mathrm{E} / \mathrm{MSY}$ with a median rate for mammals estimated at $0.3 \mathrm{E} / \mathrm{MSY}$ ) provide the best long-term estimates of the background extinction rates that have historically conserved global biodiversity. A background extinction rate of $1 \mathrm{E} / \mathrm{MSY}$ across many taxa has been proposed as a benchmark against which to assess the impacts of human actions (Pimm et al. 2006). There is ample evidence that the current and projected extinction rates are unsustainable (MEA 2005b). Nonetheless, it remains very difficult to define a boundary level for the rate of biodiversity loss that, if transgressed for long periods of time, could result in undesired, non-linear Earth System change at regional to global scales. Our primary reason for including biological diversity as a planetary boundary is its role in providing ecological functions that support biophysical sub-systems of the Earth, and thus provide the underlying resilience of other planetary boundaries. However, our assessment is that science is, as yet, unable to provide a boundary measure that captures, at an aggregate level, the regulating role of biodiversity. Instead we suggest, as an interim indicator, using extinction rate as a substitute. In doing so, we conclude that humanity has already entered deep into a danger zone where undesired system change cannot be excluded, if the current greatly elevated extinction rate (compared with the natural background extinction) is sustained over long periods of time. We suggest an uncertainty range for this undesired change of 10-100 E/MSY, indicating that a safe planetary boundary (here placed at $10 \mathrm{E} / \mathrm{MSY}$ ) is an extinction rate within an order of magnitude of the background rate. This relatively safe boundary of biodiversity loss is clearly being exceeded by at least one to two orders of magnitude, indicating an urgent need to radically reduce biodiversity loss rates (Díaz et al. 2005). A major caveat in setting a safe extinction rate is the common observation that species are not equally important for ecosystem function. In particular, the loss of top predators and structurally important species, such as corals and kelp, results in disproportionately large impacts on ecosystem dynamics.

\section{Global Freshwater Use}

The global freshwater cycle has entered the Anthropocene (Meybeck 2003) because humans are now the dominant driving force altering globalscale river flow (Shiklomanov and Rodda 2003) and the spatial patterns and seasonal timing of vapor flows (Gordon et al. 2005). An estimated $25 \%$ of the world's river basins run dry before reaching the oceans due to use of freshwater resources in the basins (Molden et al. 2007).

Global manipulations of the freshwater cycle affect biodiversity, food, and health security and ecological functioning, such as provision of habitats for fish recruitment, carbon sequestration, and climate regulation, undermining the resilience of terrestrial and aquatic ecosystems. Threats to human 
livelihoods due to deterioration of global water resources are threefold: (i) the loss of soil moisture resources (green water) due to land degradation and deforestation, threatening terrestrial biomass production and sequestration of carbon, (ii) use and shifts in runoff (blue water) volumes and patterns threatening human water supply and aquatic water needs, and (iii) impacts on climate regulation due to decline in moisture feedback of vapor flows (green water flows) affecting local and regional precipitation patterns.

Estimates indicate that $90 \%$ of global green water flows are required to sustain critical ecosystem services (Rockström et al. 1999), whereas 20\%$50 \%$ of the mean annual blue water flows in river basins are required to sustain aquatic ecosystem functioning (Smakhtin 2008).

Water-induced thresholds at the continental or planetary scale may be crossed as a result of aggregate sub-system impacts at local (e.g., river basin) or regional (e.g., monsoon system) scales (Fig. 4) caused both by changes in water resource use and climate change-induced shifts in the hydrological cycle.

Green water flows influence, at the regional scale, rainfall levels through moisture feedback and, thereby, the availability of blue water resources. Green water-induced thresholds include collapse of biological sub-systems as a result of regional drying processes. Examples include the abrupt change from a wet to a dry stable state in the Sahel region approximately 5000-6000 years BP (Scheffer et al. 2001, Foley et al. 2003) and the future risk of a rapid savannization of the Amazon rainforest due to abrupt decline in moisture feedback (Oyama and Nobre 2003). Blue water-induced thresholds include collapse of riverine habitats if minimum environmental water flow thresholds are crossed (Smakhtin 2008) and the collapse of regional lake systems (such as the Aral Sea).

A planetary boundary for freshwater resources must thus be set to safely sustain enough green water flows for moisture feedback (to regenerate precipitation), allow for the provisioning of terrestrial ecosystem functioning and services (e.g., carbon sequestration, biomass growth, food production, and biological diversity), and secure the availability of blue water resources for aquatic ecosystems. Thresholds related to moisture feedbacks occur "upstream" of and impact directly on runoff water flows. The close interactions between land and water, and between vapor flows and runoff, make it difficult to define an appropriate freshwater boundary that captures the complexity of rainfall partitioning across scales. However, as a first attempt, we propose runoff depletion in the form of consumptive runoff or blue water use as a proxy for capturing the full complexity of global freshwater thresholds.

The upper limit of accessible blue water resources is estimated at $\sim 12500-15000 \mathrm{~km}^{3} \mathrm{yr}^{-1}$ (Postel 1998, DeFraiture et al. 2001). Physical water scarcity is reached when withdrawals of blue water exceed 5000-6000 km $\mathrm{yr}^{-1}$ (Raskin et al. 1997, Vörösmarty et al. 2000, DeFraiture et al. 2001). Based on the global assessments of impacts of global green and blue water use (see Appendix 1, Supplementary Discussion 4), we estimate that transgressing a boundary of $\sim 4,000 \mathrm{~km}^{3} \mathrm{yr}^{-1}$ of consumptive blue water use (with a zone of uncertainty of 4000-6000 $\mathrm{km}^{3} \mathrm{yr}^{-1}$ ) will significantly increase the risk of approaching green and blue water-induced thresholds (collapse of terrestrial and aquatic ecosystems, major shifts in moisture feedback, and freshwater/ocean mixing) at regional to continental scales. Currently, withdrawals of blue water amount to $\sim 4,000 \mathrm{~km}^{3}$ $\mathrm{yr}^{-1}$ (Oki and Kanae 2006) whereas consumptive use is $2,600 \mathrm{~km}^{3} \mathrm{yr}^{-1}$ (Shiklomanov and Rodda 2003), leaving humanity with some room for maneuvering. However, the pressure on global freshwater resources is growing rapidly, mainly due to increasing food demands. Green water use in rainfed agriculture, currently estimated at $\sim 5000 \mathrm{~km}^{3} \mathrm{yr}^{-1}$, may have to increase by $50 \%$ by 2030 to $\sim 7500 \mathrm{~km}^{3}$ / $\mathrm{yr}$, in order to ensure food security (Rockström et al. 2007), whereas consumptive blue water use for irrigation may increase by $25 \%-50 \%$, corresponding to $400-800 \mathrm{~km}^{3} \mathrm{yr}^{-1}$ by 2050 (Comprehensive Assessment of Water Management in Agriculture 2007). This indicates that the remaining safe operating space for water may be largely committed already to cover necessary human water demands in the future.

\section{Land-System Change}

Land-system change, driven primarily by agricultural expansion and intensification, contributes to global environmental change, with the risk of undermining human well-being and long-term sustainability (Foley et al. 2005, MEA 2005a). 
Conversion of forests and other ecosystems to agricultural land has occurred at an average rate of $0.8 \% \mathrm{yr}^{-1}$ over the past $40-50$ years and is the major global driver behind loss of ecosystem functioning and services (MEA 2005a). Humanity may be reaching a point where further agricultural land expansion at a global scale may seriously threaten biodiversity and undermine regulatory capacities of the Earth System (by affecting the climate system and the hydrological cycle).

As a planetary boundary, we propose that no more than $15 \%$ of the global ice-free land surface should be converted to cropland. Because this boundary is a complex global aggregate, the spatial distribution and intensity of land-system change is critically important for the production of food, regulation of freshwater flows, and feedbacks to the functioning of the Earth System. In setting a terrestrial land boundary in terms of changes in cultivated area, we acknowledge the limitations this metric entails given the tight coupling with the other boundaries of $\mathrm{P}$ and $\mathrm{N}$ use, rate of biodiversity loss, and global freshwater use.

For humanity to stay within this boundary, cropland should be allocated to the most productive areas, and processes that lead to the loss of productive land, such as land degradation, loss of irrigation water, and competition with land uses such as urban development or biofuel production, should be controlled. Demand-side processes may also need to be managed; these include diet, per capita food consumption, population size, and wastage in the food distribution chain. Agricultural systems that better mimic natural processes (e.g., complex agroecosystems) could also allow an extension of this boundary (Ericksen et al. 2009).

Although the effects of land-system change act as a slow variable that influences other boundaries, such as biodiversity, water, and climate, they can also trigger rapid changes at the continental scale when land-cover thresholds are crossed. For example, conversion of the Amazon rainforest into cultivated or grazing systems may reach a level where an additional small amount of conversion would tip the basin into an irreversible transformation to a semi-arid savanna (Oyama and Nobre 2003, Foley et al. 2007). At the global scale, if enough high-productivity land is lost to degradation, biofuel production, or urbanization, food production may spread into marginal lands with lower yields and a higher risk of degradation.
This may constitute a threshold where a small increment of additional food production may trigger an accelerating increase in cultivated land.

The land-system boundary should be implemented at multiple scales through a fine-grained global land architecture (Turner 2009) that (i) reserves the most productive land for agricultural use, (ii) maintains high conservation-value forests and other ecosystems in their current states, and (iii) maintains carbon-rich soils and ecosystems in their undisturbed or carefully managed condition.

About $12 \%$ of the global land surface is currently under crop cultivation (Foley et al. 2005, Ramankutty et al. 2008). The allowed 3\% expansion (approximately $400 \mathrm{Mha}$ ) to the level we propose as a land-system boundary will most likely be reached over the coming decades and includes suitable land that is not either currently cultivated or is under forest cover-e.g., abandoned cropland in Europe, North America, and the former Soviet Union and some areas of Africa's savannas and South America's cerrado.

\section{Aerosol Loading}

We consider atmospheric aerosol loading as an anthropogenic global change process with a potential planetary boundary for two main reasons: (i) the influence of aerosols on the climate system and (ii) their adverse effects on human health at a regional and global scale.

Human activities since the pre-industrial era have doubled the global concentration of most aerosols (Tsigaridis et al. 2006). Aerosols ${ }^{\mathrm{iii}}$ influence the Earth's radiation balance directly by scattering incoming radiation back to space (Charlson et al. 1991, 1992) or indirectly by influencing cloud reflectivity and persistence (Twomey 1977, Albrecht 1989). Aerosols can also influence the hydrological cycle by altering the mechanisms that form precipitation in clouds (Ferek et al. 2000, Rosenfeld 2000). Aerosols may have a substantial influence on the Asian monsoon circulation (Ramanathan et al. 2005, Lau et al. 2008): absorbing aerosols over the Indo-Gangetic plain near the foothills of the Himalayas act as an extra heat source aloft, enhancing the incipient monsoon circulation (Lau and Kim 2006). The same aerosols lead to a surface cooling over central India, shifting rainfall to the Himalayan region. This "elevated heat pump" 
causes the monsoon rain to begin earlier in MayJune in northern India and the southern Tibetan plateau, increases monsoon rainfall over all of India in July-August, and reduces rainfall over the Indian Ocean. Although the influences of aerosols on the Asian monsoon are widely accepted, there is still a great deal of uncertainty surrounding the physical processes underlying the effects and the interactions between them.

$>$ From the perspective of human-health effects, fine particulate air pollution $\left(\mathrm{PM}_{2.5}\right)$ is responsible for about $3 \%$ of adult cardiopulmonary disease mortality, about $5 \%$ of tracheal, bronchial, and lung cancer mortality, and about $1 \%$ mortality from acute respiratory infection in children in urban areas worldwide (Cohen et al. 2005). These effects convert to about 800000 premature deaths and an annual loss of 6.4 million life years, predominantly in developing Asian countries. Mortality due to exposure to indoor smoke from solid fuels is about double that of urban air pollution (roughly 1.6 million deaths), and exposure to occupational airborne particulates accounts for roughly 300000 deaths per year, mainly in developing countries.

The same aerosol components (e.g., particulates, tropospheric ozone, oxides of sulphur and N) lead to other deleterious effects. Crop damage from exposure to ozone, forest degradation and loss of freshwater fish due to acidic precipitation, changes in global precipitation patterns and in energy balance are further examples of indirect effects of air pollution on human well-being.

The complexity of aerosols, in terms of the large variety of particles involved, with different sources, impacts, and spatial and temporal dynamics, makes it difficult to define a planetary boundary above which effects may cause unacceptable change. Additionally, although aerosols have been clearly linked with changes in monsoon circulation and with adverse human-health effects, the processes and mechanisms behind these correlations remain to be fully explained. For these reasons, we conclude that it is not yet possible to identify a safe boundary value for aerosol loading.

\section{Chemical Pollution}

Primary types of chemical pollution include radioactive compounds, heavy metals, and a wide range of organic compounds of human origin. Chemical pollution adversely affects human and ecosystem health, which has most clearly been observed at local and regional scales but is now evident at the global scale. Our assessment on why chemical pollution qualifies as a planetary boundary rests on two ways in which it can influence Earth System functioning: (i) through a global, ubiquitous impact on the physiological development and demography of humans and other organisms with ultimate impacts on ecosystem functioning and structure and (ii) by acting as a slow variable that affects other planetary boundaries. For example, chemical pollution may influence the biodiversity boundary by reducing the abundance of species and potentially increasing organisms' vulnerability to other stresses such as climate change (Jenssen 2006, Noyes et al. 2009). Chemical pollution also interacts with the climate-change boundary through the release and global spread of mercury from coal burning and from the fact that most industrial chemicals are currently produced from petroleum, releasing $\mathrm{CO}_{2}$ when they are degraded or incinerated as waste. There could be even more complex connections between chemical, biodiversity, and climate-change boundaries. For example, climate change will change the distributions of pests, which could lead to increased and more widespread use of pesticides.

Setting a planetary boundary for chemical pollution requires knowledge of the critical impacts on organisms of exposure to myriad chemicals and the threshold concentrations at which these effects occur. Deleterious consequences could be caused by direct exposure to chemicals in the abiotic environment-air, water, or soil-or through bioaccumulation or biomagnification up food chains, which could lead to effects in, for example, top predators.

By current estimates, there are 80000 to 100000 chemicals on the global market (U.S. Environmental Protection Agency 1998, Commission of the European Commmunities 2001). It is impossible to measure all possible chemicals in the environment, which makes it very difficult to define a single planetary boundary derived from the aggregated effects of tens of thousands of chemicals. Some toxicity data exist for a few thousand of these chemicals, but there is virtually no knowledge of their combined effects.

We can identify two complementary approaches for defining a planetary boundary for chemical pollution. One is to focus on persistent pollutants 
with global distributions, and the other to identify unacceptable, long-term, and large-scale effects on living organisms of chemical pollution.

The first approach highlights chemicals such as mercury that are capable of undergoing long-range transport via ocean or atmospheric dynamics. Specifically, it identifies pollutants that have significant effects on a range of organisms at the global scale and the threshold levels associated with these effects. Chronic, low-dose exposure may lead to subtle sub-lethal effects that hinder development, disrupt endocrine systems, impede reproduction, or cause mutagenesis. Often, younger organisms are most vulnerable to exposures to a particular pollutant (e.g., lead neurotoxicity in children). Thresholds can be identified for only a few single chemicals or chemical groups and for only a few biological species, such as some top predators (de Wit et al. 2004, Fisk et al. 2005). A well-known example is the DDT threshold concentration in the eggs of birds of prey that causes critical eggshell thinning and reproductive failure (Lincer 1975).

Although most efforts to reduce chemical pollution have focused on local and regional scales, the 2001 UN Stockholm Convention on Persistent Organic Pollutants (POPs) implicitly recognized that global concentrations of a few specific POPs (e.g., PCB, dioxins, DDT, and several other pesticides) have crossed an, as yet unquantified, planetary boundary. The bans imposed were based on known effects and observed high concentrations of these POPs in some top predators and human populations. Widening the approach from a few well-studied pollutants would require determination of critical effects for each chemical or chemical group, which is a gigantic task and would require identification of thresholds associated with mixtures of chemicals, an equally daunting challenge.

A boundary focusing on effects of chemical pollution, on the other hand, could be based on reduced or failed reproduction, neurobehavioral deficits, or compromised immune systems, which are linked to the combined exposure to many chemicals. Such a planetary boundary would need to cover subtle effects on the most sensitive life stages in the most sensitive species and/or humans, with effects observable at the global scale. An example of this approach has been reviewed based on the suggested increase in neurodevelopmental disorders such as autism and attention deficit and hyperactivity disorder (ADHD) in children. The widespread exposure to low concentrations of multiple chemicals with known or suspected neurotoxic effects may have created a silent pandemic of subtle neurodevelopmental disorders in children, possibly on a global scale (Grandjean and Landrigan 2006). Of the 80000 chemicals in commerce, 1000 are known to be neurotoxic in experiments, 200 are known to be neurotoxic in humans, and five (methyl mercury, arsenic, lead, $\mathrm{PCBs}$, toluene) are known to be toxic to human neurodevelopment.

Ultimately, a chemical pollution boundary may require setting a range of sub-boundaries based on the effects of many individual chemicals combined with identifying specific effects on sensitive organisms. Furthermore, a chemical pollution boundary interacts with the planetary boundary for aerosols, because many persistent pollutants are transported long distances on aerosol particles. In summary, however, we conclude that it is not possible at this time to define these nor is it clear how to aggregate them into a comprehensive single planetary boundary.

\section{INTERACTIONS AMONG THE BOUNDARIES}

Interactions among planetary boundaries may shift the safe level of one or several boundaries, which we have provisionally set under the (strong) assumption that no other boundaries are transgressed. In reality, what may appear as a physical boundary with a clearly defined threshold may change position as a slowly changing variable (without known global thresholds), such as the rate of biodiversity loss, exceeds its boundary level. At the aggregate level, desiccation of land due to water scarcity induced by transgressing the climate boundary, for example, may cause such a large loss of available land for agricultural purposes that the land boundary also shifts downward. At the regional scale, deforestation in the Amazon in a changing climate regime may reduce water resource availability in Asia (see Appendix 1, Supplementary Discussion 5 for other examples), highlighting the sensitivity of the water boundary to changes in the land-use and climate-change boundaries.

Tropical forests are a key component of both the regional and global energy balances and hydrological cycles. In the Amazon basin, a significant amount of the water in the atmosphere 
is recycled through the vegetation. In addition, the forest produces aerosol particles that can form cloud droplets. Changing particle concentration influences how likely the clouds are to produce rain and the strength of the convective circulation. Deforestation and biomass burning associated with land-use practices have changed convection and precipitation over the Amazon basin (Andreae et al. 2004). These changes in precipitation complete a feedback loop, because the availability of water influences the amount and kind of aerosol particles that the vegetation emits (Kesselmeier et al. 2000). Such interacting processes driven by change in land use and climate could reach a tipping point where the Amazon forest is replaced by savanna-like vegetation by the end of the 21st century (Nepstad et al. 2008).

This feedback loop is not limited to regional effects; it can also influence surface temperatures as far away as Tibet (see Fig. 5). Model simulations predict that large-scale deforestation in the northern Amazon would drastically change the surface energy balance, leading to a weakening of deep convection (Snyder et al. 2004a,b). This, in turn, would drive a weakening and northward shift in the Inter-Tropical Convergence Zone, which causes changes in the jet stream that directs the trajectory of mid-latitude weather systems, ultimately influencing surface temperature and precipitation in Tibet.

Changes in climatic conditions in Tibet directly affect much of Asia's water resources. The 15000 glaciers in the Himalaya-Hindu Kush region store an estimated $12000 \mathrm{~km}^{3}$ of freshwater, which is a main source of freshwater for roughly 500 million people in the region, plus an additional 250 million people in China (Cruz et al. 2007). Glacier melting, initially causing short-term increases in runoff, leads to increased flood risks, seasonal shifts in water supply, and increasing variability in precipitation. Although the calculated land-cover changes discussed here are extreme, the results illustrate that changes in the global climate system driven by land-use change in one region can affect water resources in other parts of the planet.

Although we have not analyzed the interactions among planetary boundaries, the examples we present suggest that many of these interactions will reduce rather than expand the boundary levels we propose, thereby shrinking the safe operating space for humanity. This suggests the need for extreme caution in approaching or transgressing any individual planetary boundaries.

\section{HUMANITY HAS ALREADY TRANSGRESSED AT LEAST THREE PLANETARY BOUNDARIES}

We have attempted to quantify the temporal trajectory of seven of the proposed planetary boundaries from pre-industrial levels to the present (Fig. 6) (see Appendix 1, Supplementary Methods 2 for data sources and data treatment). The acceleration of the human enterprise since the 1950s, particularly the growth of fertilizer use in modern agriculture, resulted in the transgression of the boundary for the rate of human interference with the global nitrogen cycle. Aggregate data over longer time periods for the biodiversity boundary are not available, but the boundary definition proposed here is greatly exceeded (even out of scale in Fig. 6, illustrated by the shading). We are not suggesting that the current state of biodiversity has passed a boundary. We are saying that the world cannot sustain the current rate of loss of species without resulting in functional collapses. It was not until the 1980s that humanity approached the climate boundary, but the trend of higher atmospheric $\mathrm{CO}_{2}$ concentration shows no signs of slowing down. In contrast, as a result of the signing of the Montreal Protocol, humanity succeeded in reversing the trend with regard to the stratospheric ozone boundary in the 1990s. As seen from Fig. 6, our estimates indicate that humanity is approaching, moreover at a rapid pace, the boundaries for freshwater use and land-system change. The ocean acidification boundary is at risk, although there is a lack of time-series data for the selected boundary variable, as well as information on the response of marine organisms and ecosystems to the projected $\mathrm{CO}_{2}$ perturbation.

\section{DISCUSSION}

There are, as far as we have determined in this proofof-concept paper, nine planetary boundaries. On condition that these are not transgressed for too long, humanity appears to have freedom to maneuver in the pursuit of long-term social and economic development within the stability domain provided by the observed resilience of the Earth System in the Holocene. 
Fig. 5. Simulated global surface temperature changes as a result of converting the tropical forest basins of the Amazon, Africa, and the Indian archipelago from rainforest to bare ground. In this simulation, changes in the tropical forest vegetation cover of the Amazon cause widespread temperature changes in the region, but also significant tele-connections to other parts of the world, including western Europe and central Asia. This simulation was performed by the CCM3 climate model, coupled to the IBIS land surface / ecosystem model (Snyder et al. 2004a,b).

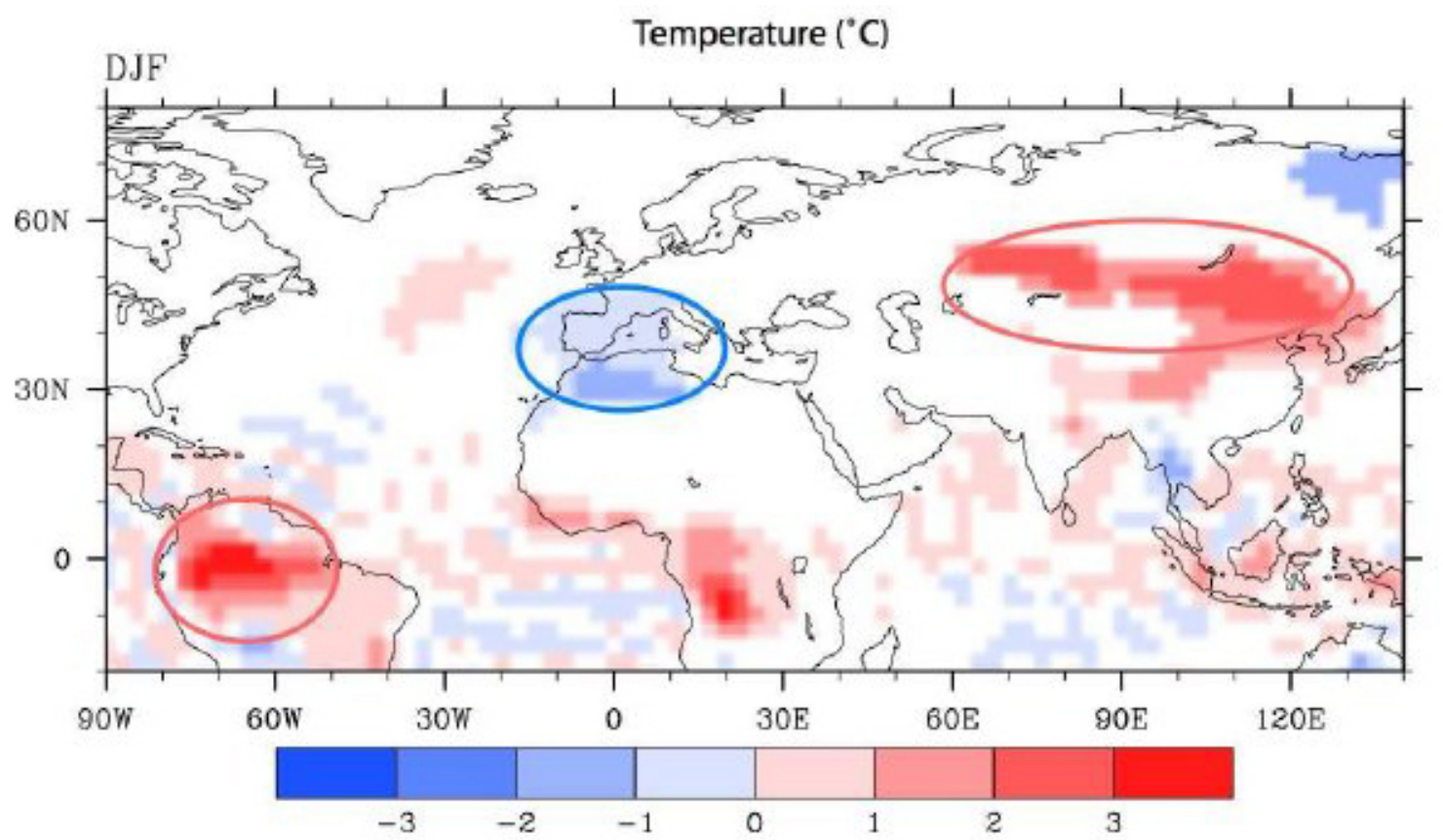

A planetary boundaries framework provides a new challenge for Earth System science and may have profound impacts on environmental governance from local to global scales. Many knowledge gaps remain, however, to implement a planetary boundaries framework. As indicated for several boundaries, they present a spatial variability and a patchiness both in terms of impacts (of transgressing a boundary level) and in terms of feedback mechanisms, which may require a widened approach combining both global and regional boundary estimates. Moreover, we are only able to quantify three with some confidence. Four are tentative suggestions, some of them only our best guesses based on the current state of knowledge. Transgressing one boundary may, furthermore, seriously threaten the ability to stay within safe levels for other boundaries. This means that no boundary can be transgressed for long periods without jeopardizing the safe operating space for humanity. Humanity thus needs to become an active steward of all planetary boundaries - the nine identified in this paper and others that may be identified in the future-in order to avoid risk of disastrous long-term social and environmental disruption.

The knowledge gaps are disturbing. There is an urgent need to identify Earth System thresholds, to analyze risks and uncertainties, and, applying a precautionary principle, to identify planetary boundaries to avoid crossing such undesired thresholds. Current governance and management paradigms are often oblivious to or lack a mandate to act upon these planetary risks (Walker et al. 2009), despite the evidence of an acceleration of anthropogenic pressures on the biophysical processes of the Earth System. Moreover, the planetary boundary framework presented here suggests the need for novel and adaptive governance 
Fig. 6. Estimate of quantitative evolution of control variables for seven planetary boundaries from preindustrial levels to the present (see Appendix 1, Supplementary Methods 2 for details). The inner (green) shaded nonagon represents the safe operating space with proposed boundary levels at its outer contour. The extent of the wedges for each boundary shows the estimate of current position of the control variable (see Table 2). Points show the estimated recent time trajectory (1950-present) of each control variable. For biodiversity loss, the estimated current boundary level of $>100$ extinctions per million species-years exceeds the space available in the figure. Although climate change, ocean acidification, stratospheric ozone depletion, land-use change, freshwater use, and interference with the phosphorus cycle are boundaries defined as the state of a variable (concentration of atmospheric $\mathrm{CO}_{2}$, aragonite saturation state, and stratospheric ozone concentration, percentage of land under crops, maximum amount of global annual freshwater use, cumulative P loading in oceans, respectively), the remaining boundary, biodiversity loss, and the component of the biogeochemical boundary related to the human interference with the $\mathrm{N}$ cycle are defined by rates of change for each respective control variable (extinctions per million species per year, rate of $\mathrm{N}_{2}$ removed from atmosphere for human use).

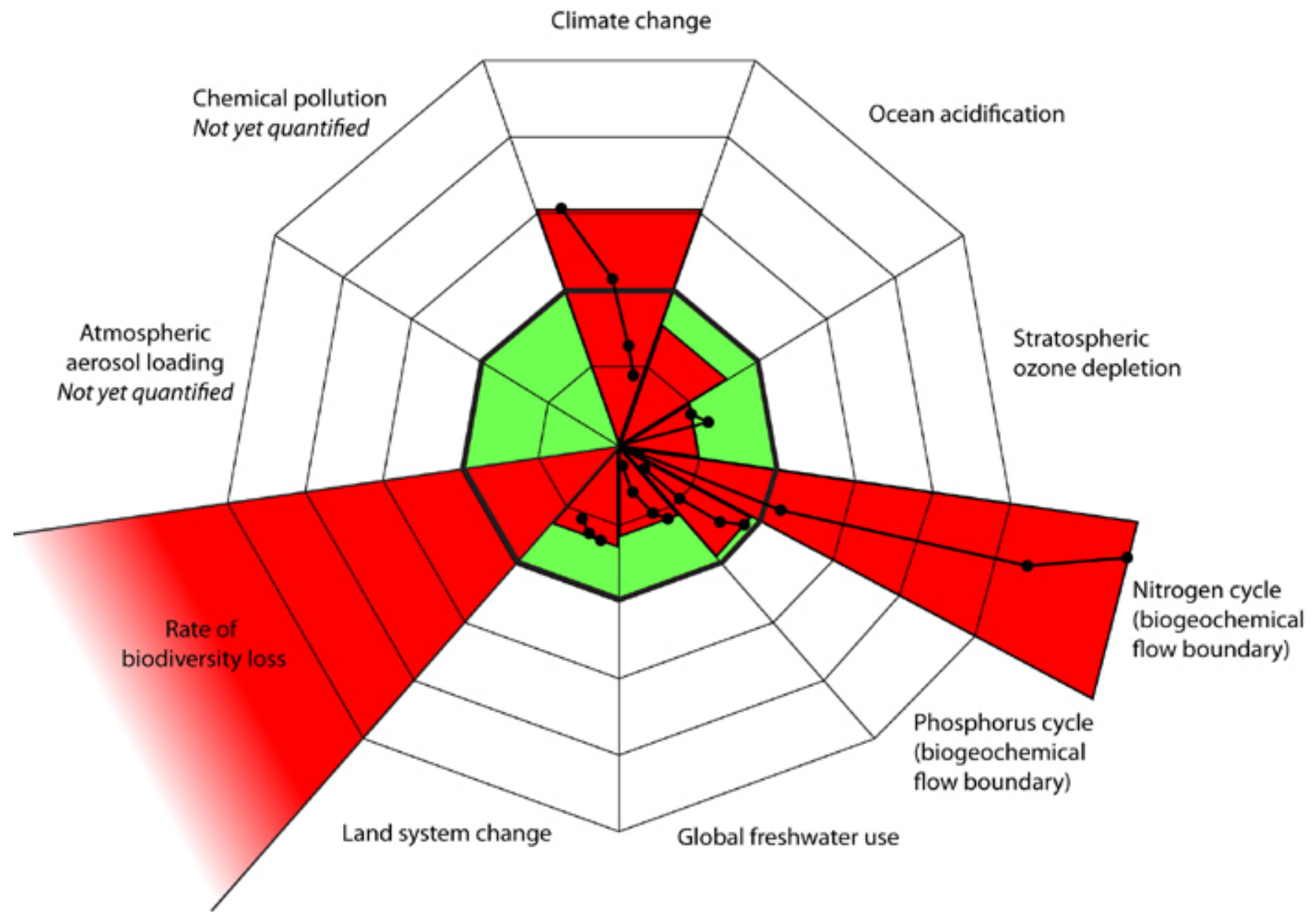


approaches at global, regional, and local scales (Dietz et al. 2003, Folke et al. 2005, Berkman and Young 2009).

Our preliminary analysis indicates that humanity has already transgressed three boundaries (climate change, the rate of biodiversity loss, and the rate of interference with the nitrogen cycle). There is significant uncertainty surrounding the duration over which boundaries can be transgressed before causing unacceptable environmental change and before triggering feedbacks that may result in crossing of thresholds that drastically reduce the ability to return within safe levels. Fast feedbacks (e.g., loss of Arctic sea ice) appear to already have kicked-in after having transgressed the climate boundary for a couple of decades. Slow feedbacks (e.g., loss of land-based polar ice sheets) operate over longer time frames. Despite the phasing-out of CFC emissions and the fact that the ozone holes did not spread beyond the polar vortex regions, which remained largely intact, the ozone holes over the polar regions will only slowly decline over the next half century.

There is little doubt, however, that the complexities of interconnected slow and fast processes and feedbacks in the Earth System provide humanity with a challenging paradox. On the one hand, these dynamics underpin the resilience that enables planet Earth to stay within a state conducive to human development. On the other hand, they lull us into a false sense of security because incremental change can lead to the unexpected crossing of thresholds that drive the Earth System, or significant subsystems, abruptly into states deleterious or even catastrophic to human well-being. The concept of planetary boundaries provides a framework for humanity to operate within this paradox.

\section{Footnotes}

i The Earth System is defined as the integrated biophysical and socioeconomic processes and interactions (cycles) among the atmosphere, hydrosphere, cryosphere, biosphere, geosphere, and anthroposphere (human enterprise) in both spatial - from local to global-and temporal scales, which determine the environmental state of the planet within its current position in the universe. Thus, humans and their activities are fully part of the Earth System, interacting with other components. ii Resilience provides a system with the ability to persist (absorb and resist shocks), adapt, and transform in the face of natural and human-induced disturbances. In this paper, our focus is on the ability of desirable (from a human perspective) states of the Earth System to persist in the face of anthropogenic disturbance.

iii Aerosols are inorganic or organic particles suspended in the atmosphere and are either directly emitted as primary aerosols (dust or particle emissions from diesel engines) or secondary aerosols, including nitrates, sulfates, ammonium compounds, and non-volatile organics, formed from conversion in atmospheric chemical reactions originating from nitrogen oxides, ammonia, and organic compounds. Aerosols vary in size, ranging from a few nanometers to tens of micrometers, and have a lifetime spanning from a couple of days to weeks, and are transported, chemically transformed, and affect areas far away from their origins. Aerosols have both a cooling effect on the climate by reflecting incoming solar radiation (e.g., from nitrates, sulfates, and sulfuric acids) and a warming effect, directly absorbing heat radiation and indirectly by changing surface albedo (e.g., black carbon soot from biomass combustion).

Responses to this article can be read online at: http://www.ecologyandsociety.org/voll4/iss2/art32/ responses/

\section{Acknowledgments:}

The broad scientific and stakeholder consultations on the planetary boundaries concept were carried out at the Tällberg Forum in June 2008, hosted by the Stockholm Resilience Centre, the Stockholm Environment Institute, and the Tällberg Foundation. A special thanks to the science-policy perspectives provided by Anders Wijkman, Martin Lees, Bo Ekman, Tariq Banuri, Christine Loh, Jacqueline McGlade, and Catherine McMullen. Paul Ehrlich, Garry Peterson, Oonsie Biggs, and Line Gordon, have provided critical inputs to the paper, and Susan Owens, Carlos Nobres, Sybil Seitzinger, and Oran Young have provided important contributions in seminars on advancing the planetary boundaries concept. Mark Lynas has provided valuable inputs for the advancement of this paper through his initiative to write a book popularizing the science 
behind our planetary boundaries analysis. The internal review process and editorial support from Nature in developing the short summary Feature article of this longer Ecology and Society article gave invaluable comments that profoundly improved both papers.

\section{LITERATURE CITED}

Albrecht, B. A. 1989. Aerosols, cloud microphysics, and fractional cloudiness. Science 245:1227-1230.

Andreae, M. O., D. Rosenfeld, P. Artaxo, A. A. Costa, G. P. Frank, K. M. Longo, and M. A. F. Silva Dias. 2004. Smoking rain clouds over the Amazon. Science 303:1337-1342.

Anthony, K. R. N., et al. 2008. Ocean acidification causes bleaching and productivity loss in coral reef builders. Proceedings of the National Academy of Sciences 105:17442-17446.

Arrow, K., B. Bolin, R. Costanza, P. Dasgupta, C. Folke, C. S. Holling, B.-O. Jansson, S. Levin, K.-G. Mäler, C. Perrings, and D. Pimentel. 1995. Economic growth, carrying capacity and the environment. Science 268:520-521.

Bellwood, D. R., T. P. Hughes, C. Folke, and M. Nyström. 2004. Confronting the coral reef crisis. Nature 429(6994):827-833.

Berger, A., and M. F. Loutre. 2002. An exceptionally long interglacial ahead? Science 297:1287-1288.

Berkman, P. A., and O. R. Young. 2009. Governance and environmental change in the Arctic Ocean. Science 324:339-340.

Biggs, R., S. R. Carpenter, and W.A. Brock. 2009. Turning back from the brink: detecting an impending regime shift in time to avert it. Proceedings of the National Academy of Sciences 106:826-831.

Bishop, R. C. 1978. Endangered species and uncertainty: the economics of a safe minimum standard. American Journal of Agricultural Economics 61:10-18.
Boulding, K.E. 1966. The economics of the coming spaceship Earth. In H. E. Daly, editor. Environmental quality issues in a growing economy. Johns Hopkins University Press, Baltimore, Maryland, USA.

Bretherton, F. 1988. Earth system sciences: a closer view. Earth System Sciences Committee, NASA, Washington, D.C., USA.

Canadell, J. G., D. Le Quéré, M. R. Raupach, C. R. Field, E. Buitenhuis, P. Ciais, T. J. Conway, N. P. Gillett, R. A. Houghton, and G. Marland. 2007. Contributions to accelerating atmospheric $\mathrm{CO}_{2}$ growth from economic activity, carbon intensity, and efficiency of natural sinks. Proceedings of the National Academy of Sciences 104:18866-18870.

Charlson, R. J., J. Langner, H. Rodhe, C. B. Leovy, and S. G. Warren. 1991. Perturbation of the northern hemisphere radiative balance by backscattering from anthropogenic sulfate aerosols. Tellus B 43 AB:152-163.

Charlson, R. J., S. E. Schwartz, J. M. Hales, R. D. Cess, J. A. Coakley, J. E. Hansen, and D. J. Hofmann. 1992. Climate forcing by anthropogenic aerosols. Science 255:423-430.

Carpenter, S. R. 2005. Eutrophication of aquatic ecosystems: bistability and soil phosphorus. Proceedings of the National Academy of Sciences 102:10002-10005.

Carpenter, S. R., D. Ludwig, and W. A. Brock. 1999. Management of eutrophication for lakes subject to potentially irreversible change. Ecological Applications 9:751-771.

Carpenter, S. R., B. Walker, J. M. Anderies, and N. Abel. 2001. From metaphor to measurement: resilience of what to what? Ecosystems 4:765-781.

Cazenave, A. 2006. How fast are the ice sheets melting? Science 314:1250-1252.

Chapin, F. S., III, E. S. Zaveleta, V. T. Eviner, R. L. Naylor, P. M. Vitousek, S. Lavorel, H. L. Reynolds, D. U. Hooper, O. E. Sala, S. E. Hobbie, M. C. Mack, and S. Diaz. 2000. Consequences of changing biotic diversity. Nature 405:234-242.

Chipperfield, M. P., V. E. Fioletov, B. Bregman, J. P. Burrows, B. J. Connor, J. D. Haigh, N. R. P. 
Harris, A. Hauchecorne, L. L. Hood, S. R. Kawa, J. W. Krzyscin, J. A. Logan, N. J. Muthama, L. Polvani, W. J. Randel, T. Sasaki, J. Stähelin, R. S. Stolarski, L. W. Thomason, and J. M. Zawodny. 2006. Global ozone: past and present. In World Meteorological Organization (WMO). Scientific assessment of ozone depletion. National Oceanic and Atmospheric Administration, National Aeronautics and Space Administration, United Nations Environment Programme, WMO, and European Commission.

Church, J. A., and N. J. White. 2006. A 20th century acceleration in global sea level rise. Geophysical Research Letters 33:LO1602.

Ciriacy-Wantrup, S. V. 1952. Resource conservation: economics and policies. University of California Press, Berkeley, California, USA.

Clark, P. U., N. G. Pisias, T. F. Stocker, and A. J. Weaver. 2002. The role of the thermohaline circulation in abrupt climate change. Nature 415:863-869.

Clark, W. C., and N. M. Dickson. 2003. Sustainability science: the emerging research program. Proceedings of the National Academy of Sciences 100:8059-8061.

Clark, W. C., and R. E. Munn, editors. 1986. Sustainable development of the biosphere. Cambridge University Press, Cambridge, UK.

Clerbaux, C., D. M. Cunnold, J. Anderson, A. Engel, P. J. Fraser, E. Mahieu, A. Manning, J. Miller, S. Montzka, R. Nassar, R. Prinn, S. Reimann, C. P. Rinsland, P. Simmonds, D. Verdonik, R. Weiss, D. Wuebbles, and Y. Yokouchi. 2006. Long-lived compounds. In World Meteorological Organization (WMO). Scientific Assessment of Ozone Depletion. National Oceanic and Atmospheric Administration, National Aeronautics and Space Administration, United Nations Environment Programme, WMO, and European Commission.

Cohen, A. J., H. R. Anderson, B. Ostro, K. D. Pandey, M. Krzyzanowski, N. Künzli, K. Gutschmidt, A. Pope, I. Romieu, J. M. Samet, and K. Smith. 2005. The global burden of disease due to outdoor air pollution. Journal of Toxicology and Environmental Health, Part A 68:1301-1307.
Commission of the European Communities. 2001. White paper: strategy for future chemicals policy. (COM2001 88 final). Commission of the European Communities., Brussels, EU.

Comprehensive Assessment of Water Management in Agriculture. 2007. Water for food, water for life: a comprehensive assessment of water management in agriculture. Earthscan and International Water Management Institute, London, UK.

Costanza, R., editor. 1991. Ecological economics: the science and management of sustainability. Columbia University Press, New York, New York, USA.

Crowards, T. 1998. Safe minimum standards: costs and opportunities. Ecological Economics 25:303314.

Crutzen, P. J. 2002. Geology of mankind: the Anthropocene. Nature 415:23.

Cruz, R. V., H. Harasawa, M. Lal, and S. A. Wu. 2007. Pages 469-506 in M. L. Parry, O. F. Canziani, J. P. Palutikof, P. J. van der Linden, and C. E. Hanson, editors. Climate change 2007: impacts, adaptation and vulnerability. Contribution of Working Group II to the Fourth Assessment Report of the Intergovernmental Panel of Climate Change. Cambridge University Press, Cambridge, UK.

Dansgaard, W., S. J. Johnsen, H. B. Clausen, D. Dahl-Jensen, N. S. Gundestrup, C. U. Hammer, C. S. Hvidberg, J. P. Steffensen, and A. E. Sveinbjörnsdottir. 1993. Evidence for general instability of past climate from a $250-\mathrm{kyr}$ ice-core record. Nature 364:218-220.

de Wit, C. A., A. T. Fisk, K. E. Hobbs, D. C. G. Muir, G. W. Gabrielsen, R. Kallenborn, M. M. Krahn, R. J. Norstrom, and J. U. Skaare. 2004. In C. A. de Wit, A. T. Fisk, K. E. Hobbs, and D. C. G. Muir, editors. AMAP assessment 2002: persistent organic pollutants in the Arctic. Arctic Monitoring and Assessment Programme, Oslo, Norway.

DeFraiture, C., D. Molden, U. Amarasinghe, and I. Makin. 2001. Podium: projecting water supply and demand for food production in 2025. Physics and Chemistry of the Earth, Part B 26:869-876. 
Díaz, S., D. Tilman, J. Fargione, F. S. Chapin, III, R. Dirzo, T. Kitzberger, B. Gemmill, M. Zobel, M. Vilà, C. Mitchell, A. Wilby, G. C. Daily, M. Galetti, W. F. Laurance, J. Pretty, R. Naylor, A. Power, and D. Harvell. 2005. Biodiversity regulation of ecosystem services. Pages 297-329 in H. Hassan, R. Scholes, and N. Ash, editors. Ecosystems and human well-being: current state and trends. Island Press, Washington, D.C., USA.

Dietz, T., E. Ostrom, and P. C. Stern. 2003. The struggle to govern the commons. Science 302:19021912 .

Doney, S. C., V. J. Fabry, R. A. Feely, and J. A. Kleypas. 2009. Ocean acidification: the other $\mathrm{CO}_{2}$ problem. Annual Review of Marine Science 1:169192.

Elmqvist, T., C. Folke, M. Nyström, G. Peterson, J. Bengtsson, B. Walker, and J. Norberg. 2003. Response diversity, ecosystem change, and resilience. Frontiers in Ecology and the Environment 1:488-494.

Ericksen, P. J., J. S. I. Ingram, D. Liverman, editors. 2009. Special issue on "Food Security and Environmental Change." Environmental Science and Policy 12(4):373-542.

Ezzati, M., A. D. Lopez, A. Rodgers, S. Vander Hoorn, and C. J. L. Murray. 2002. Selected major risk factors and global and regional burden of disease. Lancet 360:1347.

Fabry, V. J. 2008. Marine calcifiers in a high- $\mathrm{CO}_{2}$ ocean. Science 320:1020-1022.

Fabry, V. J., B. A. Seibel, R. A. Feely, and J. C. Orr. 2008. Impacts of ocean acidification on marine fauna and ecosystem processes. ICES Journal of Marine Science 65:414-432.

Feely, R.A., C. L. Sabine, J. M. Hernandez-Ayon, D. Ianson, and B. Hales. 2008. Evidence for upwelling of corrosive "acidified" water onto the continental shelf. Science 320:1490-1492.

Feely, R. A., C. L. Sabine, K. Lee, W. Berelson, J. Kleyas, V. J. Fabry, and F. J. Millero. 2004. Impact of anthropogenic $\mathrm{CO}_{2}$ on the $\mathrm{CaCO}_{3}$ system in the oceans. Science 305:362-366.

Ferek, R. J., T. Garrett, P. V. Hobbs, S. Strader, D. Johnson, J. P. Taylor, K. Nielsen, A. S.
Ackerman, Y. Kogan, Q. Liu, B.A. Albrecht, and D. Babb. 2000. Drizzle suppression in ship tracks. Journal of the Atmospheric Sciences 57:2707-2728.

Fisk, A. T., C. A. de Wit, M. Wayland, Z. Z. Kuzyk, N. Burgess, R. Letcher, B. Braune, R. Norstrom, S. Polischuk Blum, C. Sandau, E. Lie, H. J. S. Larsen, J. U. Skaare, and D. C. G. Muir. 2005. An assessment of the toxicological significance of anthropogenic contaminants in Canadian arctic wildlife. Science of the Total Environment 351-352, 57-93.

Foley, J. A., G. P. Asner, M. H. Costa, M. T. Coe, R. DeFries, H. K. Gibbs, E. A. Howard, S. Olson, J. Patz, N. Ramankutty, and P. Snyder. 2007. Amazonian revealed: forest degradation and loss of ecosystem goods and services in the Amazon Basin. Frontiers in Ecology and Environment 5(1):25-32.

Foley, J.A., M. T. Coe, M. Scheffer, and G. Wang. 2003. Regime shifts in the Sahara and Sahel: interactions between ecological and climatic systems in Northern Africa. Ecosystems 6:524-539.

Foley, J. A., R. DeFries, G. P. Asner, C. Barford, G. Bonan, S. R. Carpenter, F. S. Chapin, III, M. T. Coe, G. C. Daily, H. K. Gibbs, J. H. Helkowski, T. Holloway, E. A. Howard, C. J. Kucharik, C. Monfreda, J. A. Patz, I. C. Prentice, N. Ramankutty, and P. K. Snyder. 2005. Global consequences of land use. Science 309:570-574.

Folke, C. 2006. Resilience, the emergence of a perspective for social-ecological systems analyses. Global Environmental Change 16:253-267.

Folke, C., S. R. Carpenter, B. Walker, M. Scheffer, T. Elmqvist, L. Gunderson, and C. S. Holling. 2004. Regime shifts, resilience and biodiversity in ecosystem management. Annual Review in Ecology, Evolution and Systematics 35:557-581.

Folke, C., T. Hahn, P. Olsson, and J. Norberg. 2005. Adaptive governance of social-ecological systems. Annual Review of Environment and Resources 30:441-473.

Galloway, J. N., and E. B. Cowling. 2002. Reactive nitrogen and the world: two hundred years of change. Ambio 31:64-71.

Gordon, L., G. Peterson, and E. Bennett. 2008. Agricultural modifications of hydrological flows 
create ecological surprises. Trends in Ecology and Evolution 23:211-219.

Gordon, L., W. Steffen, B. F. Jönsson, C. Folke, M. Falkenmark, and A. Johannessen. 2005. Human modification of global water vapor flows from the land surface. Proceedings of the National Academy of Sciences 102:7612-7617.

Gunderson, L. H., and C. S. Holling, editors. 2002. Panarchy: understanding transformations in human and natural systems. Island Press, Washington, D.C., USA.

Grandjean, P., and P. J. Landrigan. 2006. Developmental neurotoxicity of industrial chemicals. Lancet 368:2167-2178.

Gruber, N., and J. N. Galloway. 2008. An earth system perspective of the global nitrogen cycle. Nature 451:293-296.

Guinotte, J. M., R.. W. Buddemeier, and J. A. Kleypas. 2003. Future coral reef habitat marginality: temporal and spatial effects of climate change in the Pacific basin. Coral Reefs 22:551558.

Guinotte, J. M., and V. J. Fabry. 2008. Ocean acidification and its potential effects on marine ecosystems. Annals of the New York Academy of Sciences 1134:320-342.

Handoh, I. C., and T. M. Lenton. 2003. Periodic mid-Cretaceous oceanic anoxic events linked by oscillations of the phosphorus and oxygen biogeochemical cycles. Global Biogeochemical Cycles 17:1092.

Hansen, J., M. Sato, P. Kharecha, D. Beerling, R. Berner, V. Masson-Delmotte, M. Pagani, M. Raymo, D. L. Royer, and J. C. Zachos. 2008. Target atmospheric $\mathrm{CO}_{2}$ : where should humanity aim? Open Atmospheric Science Journal 2:217231. doi:10.2174/1874282300802010217.

Hare, B., and M. Meinshausen. 2006. How much warming are we committed to and how much can be avoided? Climatic Change 75:111-149.

Hoegh-Guldberg, O., P. J. Mumby, A. J. Hooten, R. S. Steneck, P. Greenfield, E. Gomez, C. D. Harvell, P. F. Sale, A. J. Edwards, K. Caldeira, N. Knowlton, C. M. Eakin, R. Iglesias-Prieto, N.
Muthiga, R. H. Bradbury, A. Dubi, and M. E. Hatziolos. 2007. Coral reefs under rapid climate change and ocean acidification. Science 318:17371742 .

Hofmann, M., and H.-J. Schellnhuber. 2009. Oceanic acidification affects marine carbon pump and triggers extended marine oxygen holes. Proceedings of the National Academy of Sciences, in press. doi 10.1073/Proceedings of the National Academy of Sciences.0813384106.

Holland, J. 1996. Hidden order: how adaptation builds complexity. Basic Books, Jackson, Tennessee, USA.

Holling, C. S. 1973. Resilience and stability of ecological systems. Annual Review of Ecology and Systematics 4:1-23.

Hughes,T. P., M. J. Rodrigues, D. R. Bellwood, D. Ceccarelli, O. Hoegh-Guldberg, L. McCook, N. Moltschaniwskyj, M. S. Pratchett, R. S. Steneck, and B. Willis. 2007. Phase shifts, herbivory, and the resilience of coral reefs to climate change. Current Biology 17:360-365.

Iglesias-Rodriguez, M. D., P. R. Halloran, R. E. M. Rickaby, I. R. Hall, E. Colmenero-Hidalgo, J. R. Gittins, D. R. H. Green, T. Tyrrell, S. J. Gibbs, P. von Dassow, E. Rehm, E. V. Armbrust, and K. P. Boessenkool. 2008. Phytoplankton calcification in a high- $\mathrm{CO}_{2}$ world. Science 320:336-340.

International Panel on Climate Change (IPCC). 1990. Scientific assessment of climate change report of Working Group I. J. T. Houghton, G. J. Jenkins, and J. J. Ephraums, editors. Cambridge University Press, Cambridge, UK.

International Panel on Climate Change (IPCC). 2007a. Climate change 2007: the physical science basis. In S. Solomon, D. Qin, M. Manning, Z. Chen, M. C. Marquis, K. Avery, M. Tignor, and H. L. J. Miller, editors. Contribution of Working Group I to the Fourth Assessment Report of the Intergovernmental Panel on Climate Change. Cambridge University Press, Cambridge, UK.

International Panel on Climate Change (IPCC). 2007b. Climate change 2007: impacts, adaptation and vulnerability. In M. L. Parry, O. F. Canziani, J. P. Palutikof, P. J. van der Linden, and C. E. J. Hanson, editors. Contribution of Working Group II 
to the Fourth Assessment Report of the Intergovernmental Panel of Climate Change. Cambridge University Press, Cambridge, UK.

Jenssen, B. M. 2006. Endocrine-disrupting chemicals and climate change: a worst-case combination for Arctic marine mammals and seabirds? Environmental Health Perspectives 114:76-80.

Johannessen, O. M. 2008. Decreasing Arctic Sea ice mirrors increasing $\mathrm{CO}_{2}$ on decadal time scale. Atmospheric and Oceanic Science Letters, Institute of Atmospheric Physics, Chinese Academy of Sciences 1(1):51-56.

Kaufmann, S. A. 1993. Origins of order. Oxford University Press, New York, New York, USA.

Kesselmeier, J., U. Kuhn, A. Wolf, M. O. Andreae, P. Ciccioli, E. Brancaleoni, M. Frattoni, A. Guenther, J. Greenberg, P. D. Vasconcellos, T. de Oliva, T. Tavares, and P. Artaxo. 2000. Atmospheric volatile organic compounds (VOC) at a remote tropical forest site in central Amazonia. Atmospheric Environment 34:4063-4072.

Kleypas, J. A., R. W. Buddemeier, D. Archer, J. P. Gattuso, C. Langdon, and B. N. Opdyke. 1999. Geochemical consequences of increased atmospheric carbon dioxide on coral reefs. Science 284: 118-120.

Kuffner, I. B., A. J. Andersson, P. L. Jokiel, K. S. Rodgers, and F. T. Mackenzie. 2008. Decreased abundance of crustose coralline algae due to ocean acidification. Nature Geoscience 1:114-117.

Langdon, C., and M. J. Atkinson. 2005. Effect of elevated $\mathrm{pCO}_{2}$ on photosynthesis and calcification of corals and interactions with seasonal change in temperature/irradiance and nutrient enrichment. Journal of Geophysical Research - Oceans 110: C09S07.

Lau, K. M., and K. M. Kim. 2006. Obervational relationships between aerosol and Asian monsoon rainfall, and circulation. Geophysical Research Letters 33: L21810. doi:10.1029/2006GL027546.

Lau, K. M., V. Ramanathan, G.-X. Wu, Z. Li, S. C. Tsay, C. Hsu, R. Sikka, B. Holben, D. Lu, G. Tartari, M. Chin, P. Koudelova, H. Chen, Y. Ma, J. Huang, K. Taniguchi, and R. Zhang. 2008. The joint aerosol-monsoon experiment: a new challenge for monsoon climate research. Bulletin of the American Meteorological Society 89: 369. doi:10.1175/BAMS-89-3-369.

Lenton, T. M., H. Held, E. Kriegler, J. W. Hall, W. Lucht, S. Rahmstorf, and H. J. Schellnhuber. 2008. Tipping elements in Earth's climate system. Proceedings of the National Academy of Sciences 105:1786-1793.

Le Quéré, C., C. Rödenbeck, E. T. Buitenhuis, T. J. Conway, R. Langenfelds, A. Gomez, C. Labuschhagne, M. Ramonet, T. Nakazawa, N. Metzl, N. Gillett, and M. Heimann. 2007. Saturation of the southern ocean $\mathrm{CO}_{2}$ sink due to recent climate change. Science 316:1735-1738.

Levin, S. A. 1999. Fragile dominion: complexity and the commons. Perseus Books, Reading, Massachusetts, USA.

Lincer, J. L. 1975. DDE-induced eggshell-thinning in the American kestrel: a comparison of the field situation and laboratory results. Journal of Applied Ecology 12:781-793.

Lovelock, J. 1979. Gaia: a new look at life on Earth. Oxford University Press, New York, New York, USA.

Mace, G., H. Masundire, J. Baillie, . 2005. Biodiversity. Pages 79-115 in H. Hassan, R. Scholes, and N. J. Ash, editors. Ecosystems and human wellbeing: current state and trends. Island Press, Washington, D.C., USA.

Mackenzie, F. T., L. M. Ver, and A. Lerman. 2002. Century-scale nitrogen and phosphorus controls of the carbon cycle. Chemical Geology 190:13-32.

McNeil, B. I., and R. J. Matear. 2008. Southern ocean acidification: a tipping point at 450-ppm atmospheric $\mathrm{CO}_{2}$. Proceedings of the National Academy of Sciences 105:18860-18864.

Meadows, D. H., D. L. Meadows, J. Randers, and W. W. Behrens. 1972. The limits to growth. Universe Books, New York, New York, USA.

Meadows, D., J. Randers, and D. Meadows. 2004. Limits to growth: the 30-year update. Chelsea Green, White River Junction, Vermont, USA. 
Meybeck, M. 2003. Global analysis of river systems: from earth system controls to Anthropocene controls. Philosophical Transactions of the Royal Academy - London B 358:1935-1955.

Millennium Ecosystem Assessment (MEA). 2005a. Ecosystems and human well-being: synthesis. Island Press, Washington, D.C., USA.

Millennium Ecosystem Assessment (MEA). 2005b. Ecosystems and human well-being: biodiversity synthesis. Island Press, Washington, D. C., USA.

Miller, A. W., A. C. Reynolds, C. Sobrino, and G. F. Riedel. 2009. Shellfish face uncertain future in high $\mathrm{CO}_{2}$ world: influence of acidification on oyster larvae calcification and growth in estuaries. PLoS ONE 4(5):e5661. doi:10.1371/journal.pone.0005661.

Milly, P. C. D., R. T. Wetherald, K. A. Dunne, and T. L. Delworth. 2002. Increasing risk of great floods in a changing climate. Nature 415:514-517.

Molden, D., K. Frenken, R. Barker, C. DeFraiture, B. Mati, M. Svendsen, C. Sadoff, M. Finlayson, S. Atapattu, M. Giordano, A. Inocencio, M. Lannerstad, N. Manning, F. Molle, B. Smedema, and D. Vallee. 2007. Trends in water and agricultural development. Pages 57-89 in D. Molden, editor. Water for food, water for life: a comprehensive assessment of water management in agriculture. .Earthscan, London, UK and International Water Management Institute, Colombo, Sri Lanka.

Mucci, A. 1983. The solubility of calcite and aragonite in seawater at various salinities, temperatures, and 1 atmosphere total pressure. American Journal of Science 238:780-799.

National Research Council (NRC). 2002. Abrupt climate change: inevitable surprises. National Academy of Science, Washington, D.C., USA.

Nepstad, D. C., C. M. Stickler, B. Soares-Filho, and F. Merry. 2008. Interactions among Amazon land use, forests, and climate: prospects for a nearterm forest tipping point. Philosophical Transactions of the Royal Society B 363:1737-1746.

Noyes, P. D., M. K. McElwee, H. D. Miller, B. W. Clark, L. A. Van Tiem, K. C. Walcott, K. N. Erwin, and E. D. Levin. 2009. The toxicology of climate change: environmental contaminants in a warming world. Environment International 35, in press. doi:10.1016/j.envint.2009.02.006.

Odum, E. P. 1989. Ecology and our endangered life-support systems. Sinuaer Associates, Sunderland, Massachusetts, USA.

Oki, T., and S. Kanae. 2006. Global hydrological cycles and world water resources. Science 313:1068-1072.

Orr, J. C., V. J. Fabry, O. Aumont, L. Bopp, S. C. Doney, R. A. Feely, A. Gnanadesikan, N. Gruber, A. Ishida, F. Joos, R. M. Key, K. Lindsay, E. Maier-Reimer, R. Matear, P. Monfray, A. Mouchet, R. G. Najjar, G.-K. Plattner, K. B. Rodgers, C. L. Sabine, J. L. Sarmiento, R. Schlitzer, R. D. Slater, I. J. Totterdell, M.-F. Weirig, Y. Yamanaka, and A. Yool. 2005. Anthropogenic ocean acidification over the twentyfirst century and its impact on calcifying organisms. Nature 437:681-686.

Oyama, M. D., and C. A. Nobre. 2003. A new climate-vegetation equilibrium state for tropical South America. Geophysical Research Letters 30:2199. doi:10.1029/2003GL018600.

Petit, J. R., J. Jouzel, D. Raynaud, N. I. Barkov, J.-M. Barnola, I. Basile, M. Bender, J. Chappellaz, M. Davis, G. Delaygue, M. Delmotte, V. M. Kotlyakov, M. Legrand, V. Y. Lipenkov, C. Lorius, L. Pépin, C. Ritz, E. Saltzman, and M. Stievenard. 1999. Climate and atmospheric history of the past 420000 years from the Vostok ice core, Antartica. Nature 399:429-436.

Petschel-Held, G., H.-J. Schellnhuber, T. Bruckner, F. Tóth, and K. Hasselman. 1999. The tolerable windows approach: theoretical and methodological foundations. Climatic Change 41:303-331.

Pimm, S. L., P. Raven, A. Peterson, Ç. H. Sekercioglu, and P. Ehrlich. 2006. Human impacts on the rates of recent, present and future bird extinctions. Proceedings of the National Academy of Sciences 103(29):10941-10946.

Pimm, S. L., G. J. Russell, J. L. Gittleman, and T. M. Brooks. 1995. The future of biodiversity. Science 269:347-350. 
Postel, S. L. 1998. Water for food production: will there be enough in 2025? BioScience 48:629-638.

Raffensperger, C., and W. Tickner, editors. 1999. Protecting public health and the environment: implementing the precautionary principle. Island Press, Washington, D.C., USA.

Ramanathan, V., C. Chung, D. Kim, T. Bettge, L. Buja, J. T. Kiehl, W. M. Washington, Q. Fu, D. R. Sikka, and M. Wild. 2005. Atmospheric brown clouds: impacts on South Asian climate and hydrological cycle. Proceedings of the National Academy of Sciences 102:5326-5333.

Ramanathan, V., and Y. Feng. 2008. On avoiding dangerous anthropogenic interference with the climate system: formidable challenges ahead. Proceedings of the National Academy of Sciences 105:14245-14250.

Ramankutty, N., A. T. Evan, C. Monfreda, and J.A.Foley. 2008. Farming the planet: 1. Geographic distribution of global agricultural lands in the year 2000. Global Biogeochemical Cycles 22:GB1003. doi:10.1029/2007GB002952.

Raskin, P., P. Gleick, P. Kirshen, G. Pontius, and K. Strzepek. 1997. Water futures: assessment of long-range patterns and problems. In Stockholm Environment Institute, editor. Comprehensive assessment of the freshwater resources of the world. Stockholm Environment Institute, Stockholm, Sweden.

Richardson, K., W. Steffen, H.-J. Schellnhuber, J. Alcamo, T. Barker, D. M. Kammen, R. Leemans, D. Liverman, M. Munasinghe, B. Osman-Elasha, N. Stern, and O. Waever. 2009. Synthesis report. Climate change: global risks, challenges \& decisions. Summary of the Copenhagen climate change congress, 10-12 March 2009. University of Copenhagen, Copenhagen, Denmark.

Riebesell, U., I. Zondervan, B. Rost, P. D. Tortell, R. E. Zeebe, and F. M. M. Morel. 2000. Reduced calcification of marine plankton in response to increased atmospheric $\mathrm{CO}_{2}$. Nature 407:364-367.

Rioual, P., V. Andrieu-Ponel, M. Rietti-Shati, R. W. Battarbee, J. L. de Beaulieu, R. Cheddadi, M. Reille, H. Svobodova, and A. Shemesh. 2001.
High-resolution record of climate stability in France during the last interglacial period. Nature 413:293296.

Rockström, J., M. Falkenmark, and M. Lannerstad. 2007. Assessing the water challenge of a new green revolution in developing countries. Proceedings of the National Academy of Sciences 104:6253-6260.

Rockström, J., L. Gordon, M. Falkenmark, C. Folke, and M. Engvall. 1999. Linkages among water vapor flows, food production, and terrestrial ecosystem services. Conservation Ecology 3(2): 5. [online] URL: http://www.ecologyandsociety.org/vol3/ iss2/art5.

Rosenfeld, D. 2000. Suppression of rain and snow by urban and industrial air pollution. Science 287:1793-1796.

Sabine, C. L., R. A. Feely, N. Gruber, R. M. Key, K. H. Lee, J. L. Bullister, R. Wanninkhof, C. S. Wong, D. W. R. Wallace, B. Tilbrook, F. J. Millero, T.-H. Peng, A. Kozyr, T. Ono, and A. F. Rios. 2004. The oceanic sink for anthropogenic $\mathrm{CO}_{2}$. Science 305:367-371.

Scheffer, M. 2009. Critical transitions in nature and society. Princeton University Press, Princeton, New Jersey, USA.

Scheffer, M., and S. Carpenter. 2003. Catastrophic regime shifts in ecosystems: linking theory with observation. Trends in Ecology and Evolution 18:648-656.

Scheffer, M., S. R. Carpenter, J. A. Foley, C. Folke, and B. H. Walker. 2001. Catastrophic shifts in ecosystems. Nature 413:591-596.

Schellnhuber, H. J. 1999. Earth system analysis and the second Copernican revolution. Nature 402: C19-C22.

Schellnhuber, H. J. 2002. Coping with Earth system complexity and irregularity. Pages 151-159 in W. Steffen, J. Jaeger, D. J. Carson, and C. Bradshaw, editors. Challenges of a changing Earth. Springer Verlag, Berlin, Germany.

Seidel, D. J., and W. J. Randel. 2006. Variability and trends in the global tropopause estimated from 
radiosonde data. Journal of Geophysical Research 111:D21101. doi:10.1029/2006JD007363.

Shiklomanov, I. A., and J. C. Rodda. 2003. World water resources at the beginning of the $21^{\text {st }}$ century. UNESCO and Cambridge University Press, Cambridge, UK.

Smakhtin, V. 2008. Basin closure and environmental flow requirements. International Journal of Water Resources Development 24:227233.

Smith, R. C., B. B. Prezelin, K. S. Baker, R. R. Bidigare, N. P. Boucher, T. Coley, D. Karentz, S. MacIntyre, H. A. Matlick, and D. Menzies. 1992. Ozone depletion: ultraviolet radiation and phytoplankton biology in Antarctic waters. Science 255:952-959.

Snyder, P. K., C. Delire, and J. A. Foley. 2004a. Evaluating the influence of different vegetation biomes on the global climate. Climate Dynamics 23:279-302.

Snyder, P. K., J. A. Foley, M. H. Hitchman, and C. Delire. 2004b. Analyzing the effects of complete tropical forest removal on the regional climate using a detailed three-dimensional energy budget: an application to Africa. Journal of Geophysical Research-Atmospheres 109:D21.

Steffen, W., P. J. Crutzen, and J. R. McNeill. 2007. The Anthropocene: are humans now overwhelming the great forces of Nature? Ambio 36:614-621.

Steffen, W., A. Sanderson, J. Jäger, P. D. Tyson, B. Moore, III, P. A. Matson, K. Richardson, F. Oldfield, H.-J. Schellnhuber, B. L. Turner, II, and R. J. Wassn. 2004. Global change and the Earth system: a planet under pressure. Springer Verlag, Heidelberg, Germany.

Steinacher, M., F. Joos, T. L. Frölicher, G.-K. Plattner, and S. C. Doney. 2009. Imminent ocean acidification in the Arctic projected with the NCAR global coupled carbon cycle-climate model. Biogeosciences 6:515-533.

Stern, N. 2007. The economics of climate changethe Stern review. Cambridge University Press, Cambridge, UK.
Stone, R. 2007. A world without corals? Science 316:678-681.

Suding, K. N., S. Lavorel, F. S. Chapin, III, J. H. C. Cornelissen, S. Diaz, E. Garnier, D. Goldberg, D. U. Hooper, S. T. Jackson, and M.-L. Navas. 2008. Scaling environmental change through the community level: a trait-based response-and-effect framework for plants. Global Change Biology 14:1125-1140.

Tsigaridis, K., M. Krol, F. J. Dentener, Y. Balkanski, J. Lathière, S. Metzger, D. A. Hauglustaine, and M. Kanakidou. 2006. Change in global aerosol composition since preindustrial times. Atmospheric Chemistry and Physics 6:51435162.

Tunnicliffe, V., K. T. Davies, D. A. Buttefield, R. W. Embley, J.M. Rose, W. W. Chadwick, Jr. 2009. Survival of mussels in extremely acidic waters on a submarine volcano. Nature Geoscience 2:344348.

Turner, B. L. II. 2009. Sustainability and forest transitions in the southern Yucatán: the land architecture approach. Land Use Policy, in press. doi:10.1016/j.landusepol.2009.03.006.

Turner, B. L. II, W. C. Clark, R. W. Kates, J. F. Richards, J. T. Mathews, and W. B. Meyer, editors. 1990. The Earth as transformed by human action: global and regional changes in the biosphere over the past 300 years. Cambridge University Press, Cambridge, UK.

Twomey, S. 1977. The influence of pollution on the shortwave albedo of clouds. Journal of the Atmospheric Sciences 34:1149-1152.

Tyrrell, T. B. Schneider, A. Charalampopoulou, and U. Riebesell. 2008. Coccolithophores and calcite saturation state in the Baltic and Black Seas. Biogeosciences 5:485-494.

U.S. Environmental Protection Agency. 1998. Chemical hazard data availability study: what do we really know about the safety of high production volume chemicals? Office of Pollution Prevention and Toxics, Washington, D.C., USA.

van der Leeuw, S. E. 2008. Climate and society: lessons from the past 10000 years. Ambio $\mathbf{1 4}$ (Special Issue):476-482. 
Vitousek, P. M., H.A. Mooney, J. Lubchenco, and J. M. Melillo. 1997. Human domination of the Earth's ecosystems. Science 277:494-499.

Vörösmarty, C. J., P. Green, J. Salisbury, and R. B. Lammers. 2000. Global water resources: vulnerability from climate change and population growth. Science 289:284-288.

Walker, B. H., S. Barrett, V. Galaz, S. Polasky, C. Folke, G. Engström, F. Ackerman, K. Arrow, S. R. Carpenter, K. Chopra, G. Daily, P. Ehrlich, T. Hughes, N. Kautsky, S. A. Levin, K.-G. Mäler, J. Shogren, J. Vincent, T. Xepapadeous, and A. de Zeeuw. 2009. Looming global-scale failures and missing institutions. Science, in press.

Walker, B., C. S. Holling, S. R. Carpenter, and A. Kinzig. 2004. Resilience, adaptability and transformability in social-ecological systems. Ecology and Society 9(2): 5. [online] URL: http://w ww.ecologyandsociety.org/vol9/iss2/art5.

Walker, B., A. Kinzig, and J. Langridge. 1999. Plant attribute diversity, resilience, and ecosystem function: the nature and significance of dominant and minor species. Ecosystems 2:95-113.

WBGU (German Advisory Council on Global Change). 1995. Scenario for the derivation of global $\mathrm{CO}_{2}$ reduction targets and implementation strategies. Statement on the occasion of the First Conference of the Parties to the Framework Convention on Climate Change in Berlin. March 1995. URL: http://www.wbgu.de/wbgu sn1995 engl. pdf.

Wood, H. L., J. I. Spicer, and S. Widdicombe. 2008. Ocean acidification may increase calcification rates, but at a cost. Proceedings of the Royal Society B 275:1767-1773.

World Meteorological Organization (WMO). 1990. Scientific assessment of stratospheric ozone: 1989. Volume 1, Report 20. WMO, Geneva, Switzerland.

Young, O. R., and W. Steffen. 2009. The Earth system: sustaining planetary life-support systems. Pages 295-315 in F. S. Chapin, III, G. P. Kofinas, and C. Folke, editors. Principles of ecosystem stewardship: resilience-based natural resource management in a changing world. Springer, New York, New York, USA.
Zillén, L., D. J. Conley, T. Andrén T., E. Andrén, and S. Björck. 2008. Past occurrences of hypoxia in the Baltic Sea and the role of climate variability, environmental change, and human impact. Earth Science Reviews 91:77-92. 
Appendix 1. Supplementary Information.

Please click here to download file 'appendix1.pdf'. 